\title{
Identification of Selected Areas to Support Federal Clean Energy Goals Using Small Modular Reactors
}

\section{December 2013}

Prepared by

R. J. Belles

G. T. Mays

O. A. Omitaomu

W. P. Poore

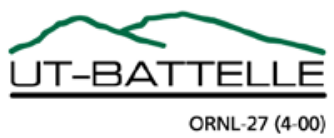




\title{
DOCUMENT AVAILABILITY
}

Reports produced after January 1, 1996, are generally available free via the U.S. Department of Energy (DOE) Information Bridge.

Web site http://www.osti.gov/bridge

Reports produced before January 1, 1996, may be purchased by members of the public from the following source.

\author{
National Technical Information Service \\ 5285 Port Royal Road \\ Springfield, VA 22161 \\ Telephone 703-605-6000 (1-800-553-6847) \\ TDD 703-487-4639 \\ Fax 703-605-6900 \\ E-mail info@ntis.gov \\ Web site http://www.ntis.gov/support/ordernowabout.htm
}

Reports are available to DOE employees, DOE contractors, Energy Technology Data Exchange (ETDE) representatives, and International Nuclear Information System (INIS) representatives from the following source.

Office of Scientific and Technical Information

P.O. Box 62

Oak Ridge, TN 37831

Telephone 865-576-8401

Fax 865-576-5728

E-mail reports@osti.gov

Web site http://www.osti.gov/contact.html

This report was prepared as an account of work sponsored by an agency of the United States Government. Neither the United States Government nor any agency thereof, nor any of their employees, makes any warranty, express or implied, or assumes any legal liability or responsibility for the accuracy, completeness, or usefulness of any information, apparatus, product, or process disclosed, or represents that its use would not infringe privately owned rights. Reference herein to any specific commercial product, process, or service by trade name, trademark, manufacturer, or otherwise, does not necessarily constitute or imply its endorsement, recommendation, or favoring by the United States Government or any agency thereof. The views and opinions of authors expressed herein do not necessarily state or reflect those of the United States Government or any agency thereof. 


\title{
IDENTIFICATION OF SELECTED AREAS TO SUPPORT FEDERAL CLEAN ENERGY GOALS USING SMALL MODULAR REACTORS
}

\author{
R. J. Belles \\ G. T. Mays \\ O. A. Omitaomu \\ W. P. Poore \\ Date Published: December 2013 \\ Prepared for \\ U.S. Department of Energy, Office of Nuclear Energy \\ Prepared by \\ OAK RIDGE NATIONAL LABORATORY \\ Oak Ridge, Tennessee 37831-6283 \\ managed by \\ UT-BATTELLE, LLC \\ for the \\ U.S. DEPARTMENT OF ENERGY \\ under contract DE-AC05-00OR22725
}





\section{CONTENTS}

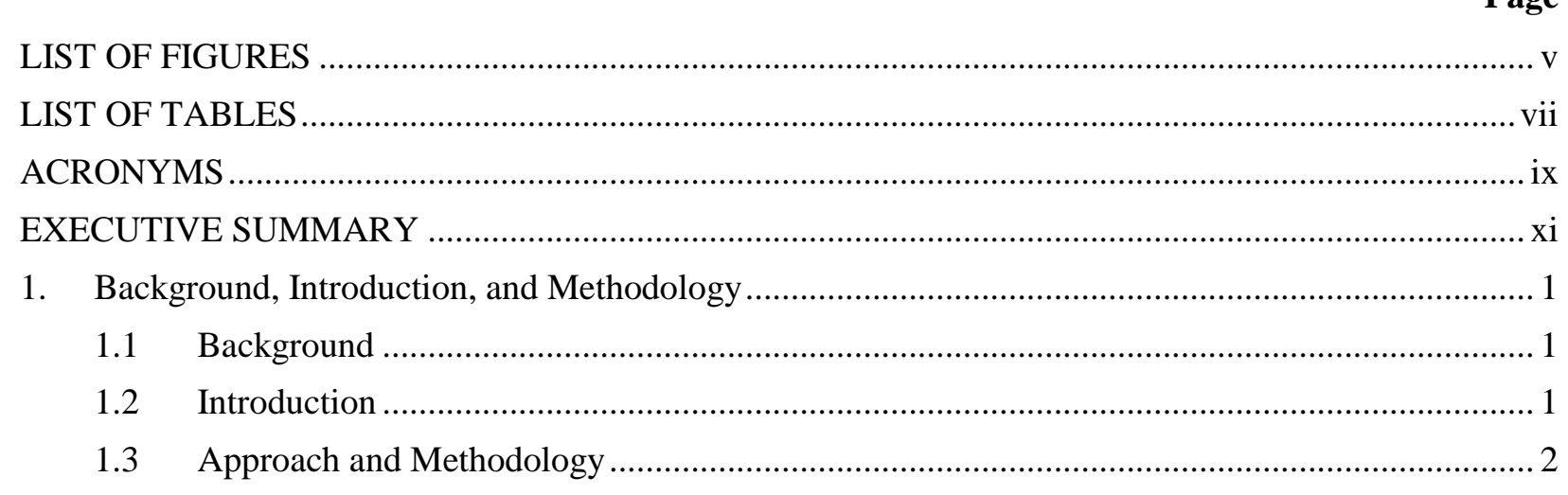

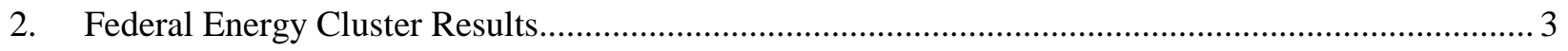

$2.1 \quad$ Energy Demand of Non-DoD Facilities .......................................................................... 4

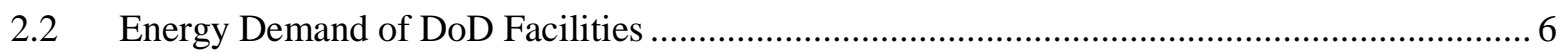

2.3 Combined Energy Demand of Federal Facilities ................................................................... 8

2.4 Federal Energy Clusters Relative to SMR Candidate Areas ................................................. 13

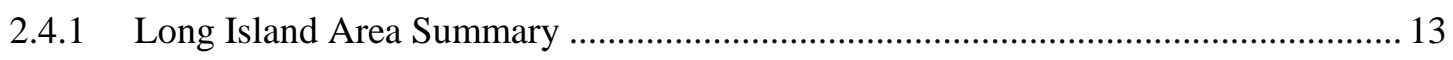

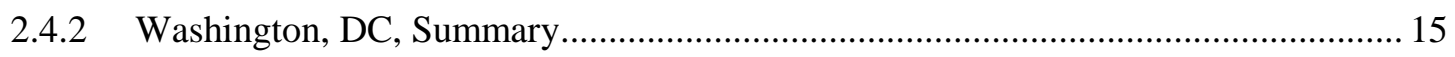

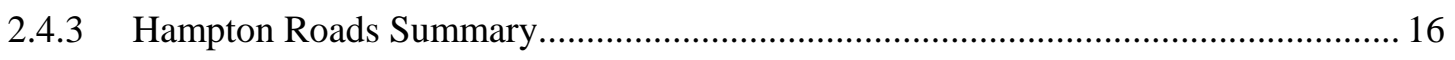

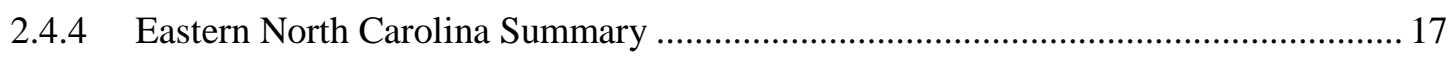

2.4.5 South Carolina and Eastern Georgia Summary ...................................................... 18

2.4.6 Florida Panhandle, Southeastern Alabama, and Southwestern Georgia Summary .... 19

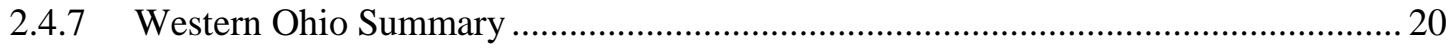

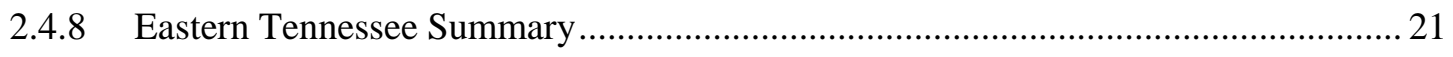



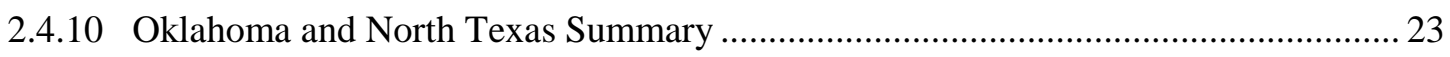

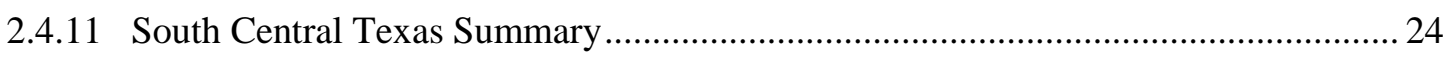

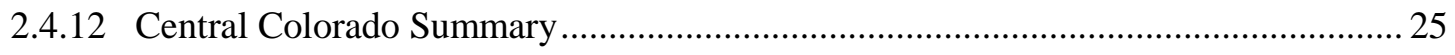

2.4.13 Southern California Summary .......................................................................... 26

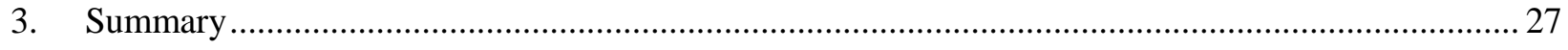

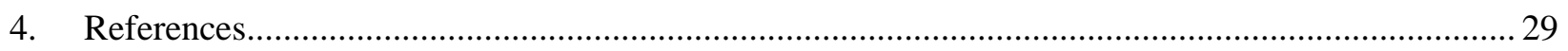





\section{LIST OF FIGURES}

Figure $\quad$ Page

Fig. ES-1. Combined federal energy consumption by two-digit ZIP code area. ......................................xii

Fig. ES-2. SMR composite map detailing siting challenges..................................................................iii

Fig. 1. Comparison of large PWR design with iPWR design for SMRs. ${ }^{8}$............................................... 3

Fig. 2. Energy consumption at reported non-DoD facilities. ........................................................... 5

Fig. 3. Energy consumption at reported DoD facilities. .................................................................. 7

Fig. 4. Energy consumption at reported DoD and non-DoD facilities.................................................... 8

Fig. 5. Combined federal energy consumption in the Northeast............................................................. 9

Fig. 6. Combined federal energy consumption in the Southeast............................................................ 9

Fig. 7. Combined federal energy consumption summed by state. ....................................................... 10

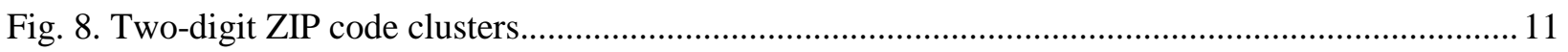

Fig. 9. Combined federal energy consumption by two-digit ZIP code area............................................ 11

Fig. 10. Long Island, New York area relative to SMR siting criteria................................................... 14

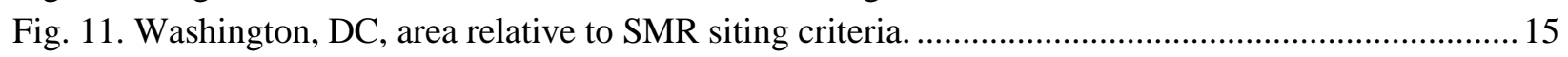

Fig. 12. Hampton Roads area relative to SMR siting criteria................................................................. 16

Fig. 13. Eastern North Carolina area relative to SMR siting criteria...................................................... 17

Fig. 14. South Carolina and eastern Georgia area relative to SMR siting criteria.................................... 18

Fig. 15. Florida Panhandle, Alabama, and Georgia area relative to SMR siting criteria.......................... 19

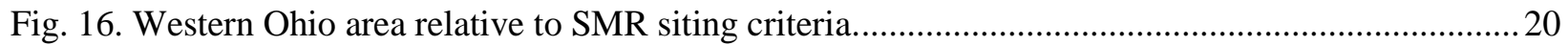

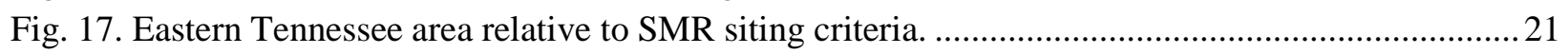

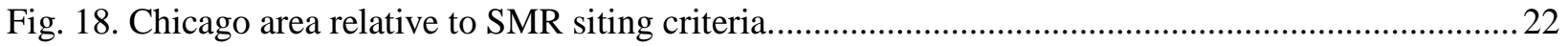

Fig. 19. Oklahoma and North Texas area relative to SMR siting criteria................................................23

Fig. 20. South central Texas area relative to SMR siting criteria. .........................................................24

Fig. 21. Central Colorado area relative to SMR siting criteria. ............................................................25

Fig. 22. Southern California area relative to SMR siting criteria. ...........................................................26 



\section{LIST OF TABLES}

\section{Table}

Page

Table ES-1. List of Top Federal Energy Clusters.................................................................................xiii

Table 1. Top Non-DoD Energy Consumption Locations …....................................................................

Table 2. Top DoD Energy Consumption Locations ....................................................................... 7

Table 3. Top Combined Federal Energy Consumption Locations by Two-Digit ZIP Code....................... 12

Table 4. Top Combined Federal Energy Consumption Locations by Visual Analysis ............................. 12

Table 5. Summary of Top Federal Energy Clusters........................................................................... 27 



\section{ACRONYMS}

$\begin{array}{ll}\text { B\&W } & \text { Babcock and Wilcox } \\ \text { BTU } & \text { British Thermal Unit } \\ \text { BWR } & \text { boiling-water reactor } \\ \text { DoD } & \text { U.S. Department of Defense } \\ \text { DOE } & \text { U.S. Department of Energy } \\ \text { EERE } & \text { (DOE) Office of Energy Efficiency and Renewable Energy } \\ \text { FEMP } & \text { Federal Energy Management Program } \\ \text { GIS } & \text { geographic information systems } \\ \text { HEMSFs } & \text { high-energy mission specific facilities } \\ \text { iPWR } & \text { integral pressurized-water reactor } \\ \text { LWR } & \text { light-water reactor } \\ \text { MW(e) } & \text { megawatt electrical } \\ \text { NE } & \text { (DOE) Office of Nuclear Energy } \\ \text { NRC } & \text { U.S. Nuclear Regulatory Commission } \\ \text { ORNL } & \text { Oak Ridge National Laboratory } \\ \text { OR-SAGE } & \text { Oak Ridge Siting Analysis for Power Generation Expansion } \\ \text { PWR } & \text { pressurized-water reactor } \\ \text { SMR } & \text { small modular reactor } \\ \text { SSEC } & \text { site selection and evaluation criteria } \\ \text { VSEC } & \text { Virginia-Hampton Roads SMR Energy Development Council } \\ \text { ZIP code } & \text { Postal Zone Improvement Plan Code } \\ & \end{array}$





\section{EXECUTIVE SUMMARY}

Beginning in late 2008, Oak Ridge National Laboratory (ORNL) responded to ongoing internal and external studies addressing key questions related to our national electrical energy supply. This effort has led to the development and refinement of Oak Ridge Siting Analysis for power Generation Expansion (OR-SAGE), a tool to support power plant siting evaluations. The objective in developing OR-SAGE was to use industry-accepted approaches and/or develop appropriate criteria for screening sites and employ an array of geographic information systems (GIS) data sources at ORNL to identify candidate areas for a power generation technology application. The basic premise requires the development of exclusionary, avoidance, and suitability criteria for evaluating sites for a given siting application, such as siting small modular reactors (SMRs). For specific applications of the tool, it is necessary to develop site selection and evaluation criteria (SSEC) that encompass a number of key benchmarks that essentially form the site environmental characterization for that application. These SSEC might include population density, seismic activity, proximity to water sources, proximity to hazardous facilities, avoidance of protected lands and floodplains, susceptibility to landslide hazards, and others.

The OR-SAGE tool is essentially a dynamic visualization database. The SSEC are the fields of the database, and the GIS data for a given variable represent the values against which searches are performed. The evaluation process divides the contiguous United States into 100- by 100-m (1 hectare) squares (cells), applying successive SMR-appropriate SSEC to each cell. There are just under 700 million cells representing the contiguous United States. If a cell meets the requirements of each SMR criterion, the cell is included as a candidate to be integrated in the possible siting of an SMR. Some SSEC parameters preclude siting a facility because of an environmental, regulatory, or land-use constraint. Other SSEC assist in identifying less favorable areas, such as proximity to hazardous operations. All of the selected SSEC tend to recommend against sites; that is, they tend to identify areas in which there are challenges to using the site for the purpose of interest. The strength of the OR-SAGE tool is that numerous alternative scenarios can be quickly generated to provide additional insight into SMR electrical generation or other GIS-based applications.

This report documents the identification of U.S. locations to possibly site new SMR nuclear power plants in areas where the concentration and electricity use by federal government agencies is high and forecasted to grow in the next 10 years. "Federal agencies" include military and other agencies (e.g., Homeland Security, DOE, FBI, and Social Security Administration) that have missions of national critical importance.

Historical Department of Defense (DoD) facility energy consumption data for FY 2010 and FY 2011 were averaged and analyzed. Likewise, historical DOE Federal Energy Management Program facility energy consumption data for all non-DoD federal facilities provided facility annual detail data for FYs 2009-2012 and were averaged and analyzed. Only data for federal facilities in the contiguous United States were mapped in this analysis. This information was analyzed by postal ZIP code using spatial modeling and GIS. Energy consumption data from sensitive federal facilities is not included.

The postal Zone Improvement Plan (ZIP) Code system breaks the country into 99 "mostly" contiguous areas. These areas are identified by the first two digits of the ZIP code and can be seen individually in Fig. 8 in the body of the report. The combined federal energy data were sorted by the first two digits of the ZIP code, binned, and plotted, as shown in Fig. ES-1. The orange, dark blue, and red colored areas in Fig. ES-1 have higher federal energy consumption. For clarity, the only dark blue areas are in Virginia, North Carolina, and Washington. This depiction allows clustered areas within state boundaries to be more visually obvious, as well as potential multi-state areas. Note that eastern Washington, which is dark blue, shares the same two-digit ZIP code area (99) as all of Alaska. The dark blue color in eastern Washington is a result of the power demand in Alaska. Much of the country shown in Fig. ES-1 is binned into the lower energy consumption categories shown in light blue and purple. 


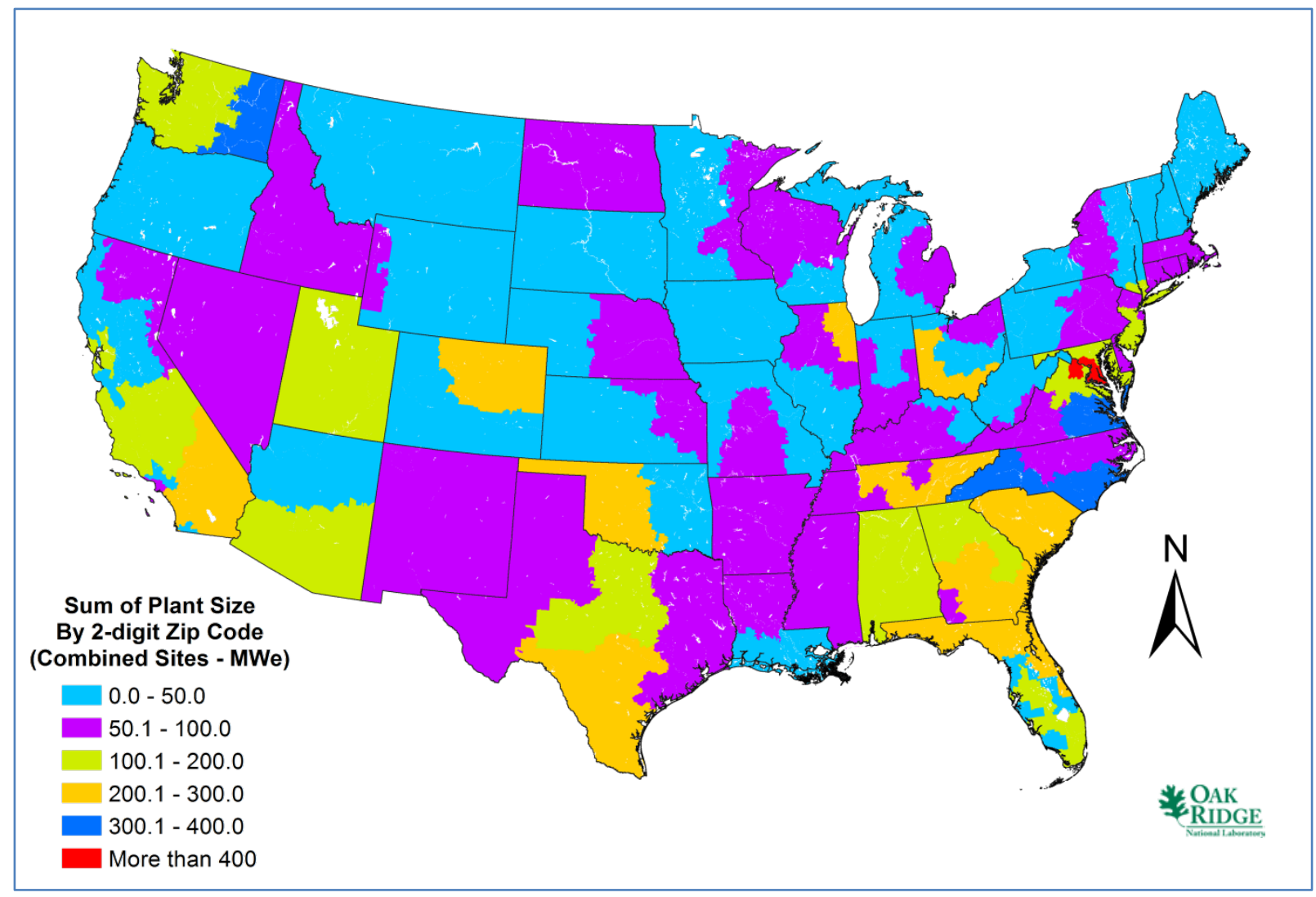

Fig. ES-1. Combined federal energy consumption by two-digit ZIP code area.

Energy consumption data for federal facilities over a multi-year period were analyzed mathematically using spreadsheet manipulations and visually using GIS layers. Energy clusters among these federal facilities were identified using the above methods. Some of the facility clusters are relatively compact, and others require a very broad definition for a facility cluster (i.e., covering a significant distance or range to supply power to all facilities in the cluster). Thirteen clusters identified by one or both methodologies were analyzed against SMR siting criteria, without consideration for surrounding population, which is to be analyzed later.

The potential federal energy cluster sites were then overlaid onto an SMR candidate area map generated by OR-SAGE. The OR-SAGE tool can visually display individual cells that are clear of all the SSEC layer exclusions and can track and display cells that are tripped by one, two, or three or more exclusions. All the SMR SSEC are applied to the national map shown in Fig. ES-2, including the population criterion. The areas shown in green in Fig. ES-2 are clear of all the SSEC layer exclusions at the specified threshold value. Further analysis within the body of this task report does not apply the population criterion to individual clusters because sensitivity to population will be explored in a later project task. Not including the population criterion has the effect of slightly increasing the green space depicted in Fig. ES-2. This final check of the 13 identified federal energy clusters provided insight into the unobstructed potential for centrally siting an SMR near a possible federal energy consumption cluster. 


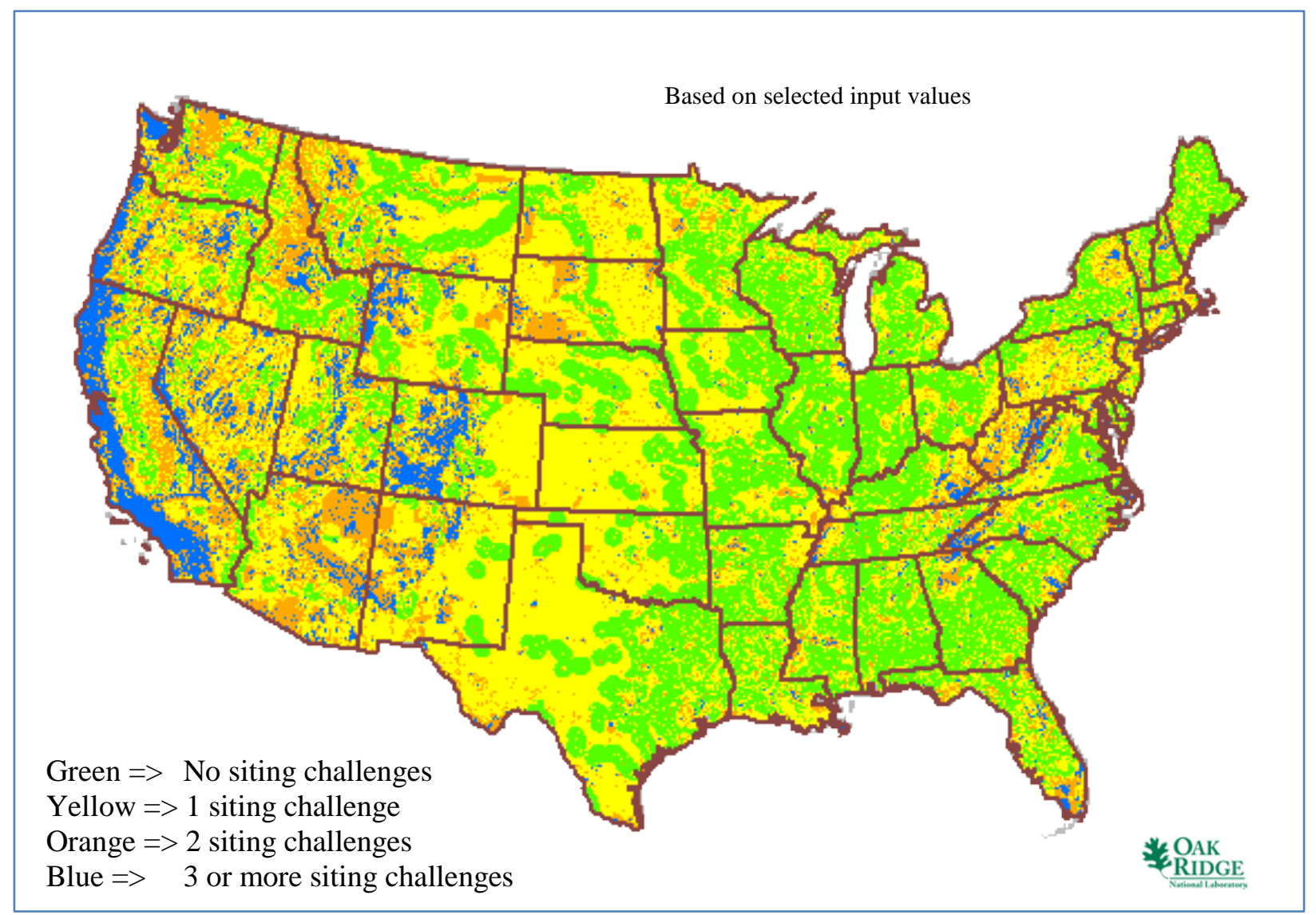

Fig. ES-2. SMR composite map detailing siting challenges.

Eight energy clusters were selected as areas with significant energy consumption based on historical data and providing favorable opportunities for SMR siting to possibly meet federal clean energy goals. These eight federal energy clusters should be explored further regarding their potential for using an SMR to help meet federal clean energy goals. The Virginia Hampton Roads area will be explored in more detail in the subsequent tasks of this project. The top clusters, in order of past energy demand, are identified in Table ES-1.

Table ES-1. List of Top Federal Energy Clusters

\begin{tabular}{|l|}
\hline Location/Facility \\
\hline Virginia Peninsula/Hampton Roads area \\
\hline Savannah River Site, South Carolina \\
\hline Florida Panhandle \\
\hline South Central Texas \\
\hline Denver-Colorado Springs, Colorado \\
\hline East Tennessee/ORNL \\
\hline Southwest Oklahoma-North Texas \\
\hline Western Ohio \\
\hline
\end{tabular}




\section{BACKGROUND, INTRODUCTION, AND METHODOLOGY}

\section{$1.1 \quad$ Background}

The U.S. Department of Energy (DOE) Office of Nuclear Energy (NE) has previously tasked Oak Ridge National Laboratory (ORNL) to support identification of candidate sites for new small modular reactor (SMR) power plants using an ORNL geographic information system (GIS)-based tool. ${ }^{1,2}$ The tool, Oak Ridge Siting Analysis for power Generation Expansion (OR-SAGE), is a flexible system being used to evaluate power plant siting options and considerations for a variety of power sources and to identify nuclear waste storage siting options. The objective in developing OR-SAGE was to merge industryaccepted approaches for screening sites with the array of GIS data sources at ORNL to identify candidate areas for a particular application.

Recently, DOE-NE staff met with members of the Virginia-Hampton Roads SMR Energy Development Council (VSEC) to understand how nuclear energy in general, and SMRs in particular, fit into future plans for secure and reliable energy for the Hampton Roads, Virginia, metro area. This partnership has been promoting the use of SMRs as a means of meeting federal clean energy goals.

The constituents of VSEC are the Jefferson National Laboratory, Huntington-Ingalls Newport News Shipyard, Virginia Electric and Power Company (Dominion), Babcock and Wilcox (B\&W) Generation mPower, and an economic development group called the Hampton Roads Military and Federal Facilities Alliance. VSEC has identified a number of potential locations for siting SMRs on or near federal government property. Dominion Energy has performed an initial but limited desktop siting review. The current federal electricity use in this area is estimated by Dominion Energy at over 500 megawatts with potential for significant growth based on expansion of the Jefferson Laboratory National Accelerator Facility and other economic growth in the area. DOE-NE requested that similar federal agency energy clusters throughout the United States also be identified for further analysis. This report documents additional federal agency energy clusters that may subsequently warrant additional analysis in support of meeting federal clean energy goals. These federal power clusters will be identified based upon power usage data, geographical concentration (collocation) of federal agencies, or operation of large federal data centers.

ORNL staff previously evaluated screening criteria for large and small nuclear power plants, advanced coal plants with carbon sequestration, wet and dry solar power technologies (excluding photovoltaic cells), and compressed air energy storage for the Electric Power Research Institute. ${ }^{3}$ ORNL staff also evaluated repowering select coal plants with an $\mathrm{SMR}^{4}$ and powering select military and DOE facilities with a dedicated SMR. ${ }^{5}$

\subsection{Introduction}

The objective of this research project is to support DOE-NE in evaluating future electrical generation deployment options for SMRs in areas with significant energy demand from the federal sector. Deployment of SMRs in zones with high federal energy use will provide a means of meeting federal clean energy goals.

This report identifies several locations with a high concentration of federal government agency electricity usage. One such location, the Hampton Roads area in Virginia, will be studied in further detail with the assistance of the Hampton Roads Energy Corridor Partnership. The Hampton Roads evaluation will be documented in a subsequent report.

This research project is aimed at providing methodologies, information, and insights to assist the federal government in meeting federal clean energy goals. The evaluation is based on previously developed 
screening criteria and the application of spatial modeling and GIS. For reference purposes, the B\&W Generation mPower SMR technology will be used for all analyses. A generalized SMR plant parameter envelope will be used to conduct evaluations when other SMR technology information becomes available.

\subsection{Approach and Methodology}

This report documents the identification of U.S. locations to possibly site new SMR nuclear power plants in areas where the concentration and electricity use by federal government agencies is high and forecasted to grow in the next 10 years. "Federal agencies" include military and other agencies (e.g., Homeland Security, DOE, FBI, and Social Security Administration) that have missions of national critical importance. Energy consumption data from sensitive federal facilities is not included.

The Department of Defense (DoD) Annual Energy Management Report for Fiscal Year (FY) 2011 provided the energy use data for DoD facilities worldwide. ${ }^{6}$ Data for FY 2010 and FY 2011 were provided in the report, which were averaged for the purposes of this analysis. Only data for DoD facilities in the contiguous United States are followed in this analysis.

The DOE Office of Energy Efficiency and Renewable Energy (EERE) Federal Energy Management Program provided the energy use data for all non-DoD federal facilities. ${ }^{7}$ The Compliance Tracking System Data Warehouse provided facility annual detail data for FYs 2009-2012, which was averaged for the purposes of this analysis. Only data for non-DoD federal facilities in the contiguous United States were tracked in this analysis.

This information was analyzed by postal ZIP code using spatial modeling and GIS. Some facilities utilized a ZIP code unique to that facility and were not spatially represented. In those cases, Google Earth software was used to identify the ZIP code that encompassed the facility of interest. Clusters were identified directly by ZIP code area analysis and visually using GIS information.

Not all facilities reported consistently over the report periods, so data were averaged to simplify the comparison. Energy records were reported in British Thermal Units (BTUs). These were converted to relative plant size in megawatts [MW(e)] required to meet the average annual energy load. A 90\% plant capacity factor was assumed, which is consistent with SMR design detail and the fleet-wide performance of current nuclear power plants. No facility peak power demand was considered. However, the average annual load is sufficient to identify federal energy clusters of interest on a regional basis. 


\section{FEDERAL ENERGY CLUSTER RESULTS}

This analysis identifies candidate locations, in a broad sense, where there are high concentrations of federal government agency use of electricity, which are also suitable areas for near-term SMRs. Nearterm SMRs are based on light-water reactor (LWR) technology with compact design features that are expected to offer a host of safety, siting, construction, and economic benefits. These smaller plants are ideally suited for small electric grids and for locations that cannot support large reactors, thus providing utilities or governement entities with the flexibility to scale power production as demand changes by adding additional power by deploying more modules or reactors in phases. The near-term SMR designs are based on existing pressurized-water reactor (PWR) technology. They are characterized as "integral” PWRs (iPWRs) since these plants will have major equipment such as pumps, steam generators, and pressurizers all located within the pressure vessel in an integrated, compact design. Individual reactor units in these designs are typically in the 45- to 250-MW(e) power range.

The principal design differences between an iPWR and a conventional loop-type PWR are shown in Fig. 1. The schematic in Fig. 1 shows that the coolant loop piping for the large PWR, with two, three, or four loops (only one pictured) is eliminated; piping that penetrates the reactor vessel is significantly smaller in the iPWR; and the major equipment for the iPWR is located within the pressure vessel. Another distinguishing design feature that is not illustrated in Fig. 1 is the elongated (taller) core design for the iPWR. The vessel height-to-diameter ratio for the near-term iPWRs will likely exceed 6.0, while that of a PWR and a boiling-water reactor (BWR) is on the order of 2.5 and 2.0, respectively. This increase in the aspect ratio greatly facilitates the formation of gravity-driven natural convection circulation of the coolant, which enhances heat removal from the core and allows the plant to cool down safely in the event of a loss of off-site power without a requirement for emergency power (diesels or batteries) to drive circulation pumps. ${ }^{8}$

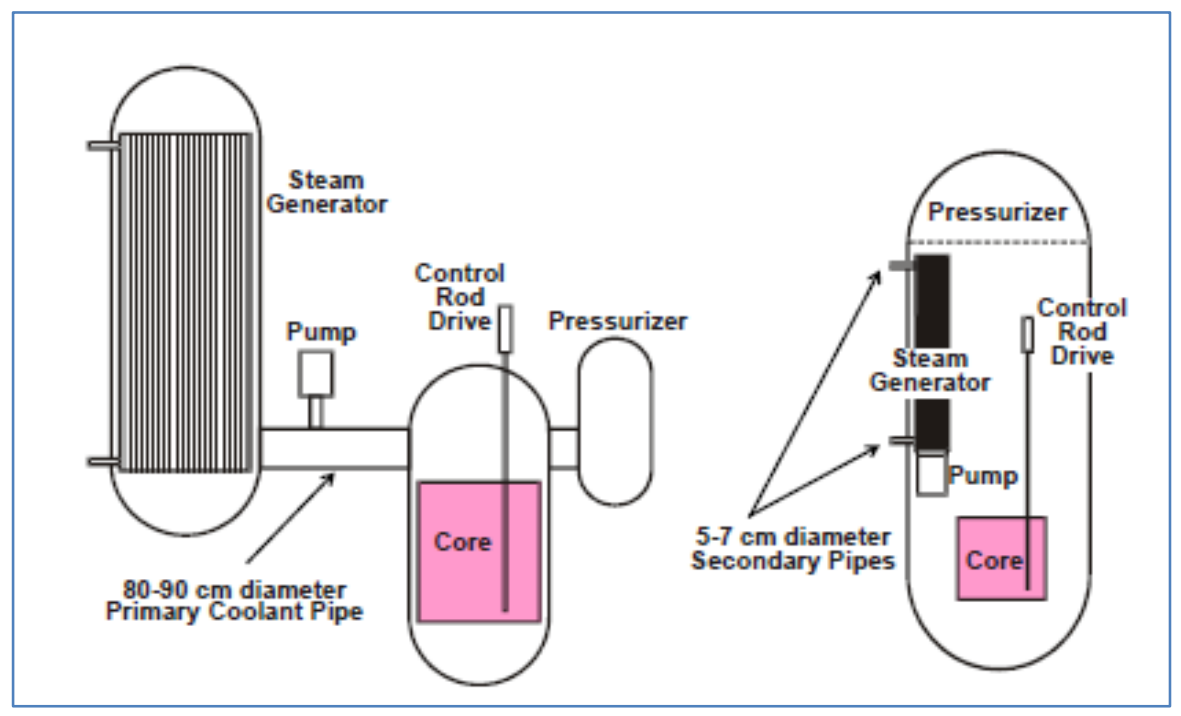

Fig. 1. Comparison of large PWR design with iPWR design for SMRs. ${ }^{8}$

The four SMR vendors whose integral designs are based on PWR technology include

- B\&W mPower SMR: 180 MW(e) per reactor module with the plan to deploy two 180 MW(e) modules/units at a time;

- NuScale SMR: 45 MW(e) per reactor module with the plan to deploy these modules/units 6 or 12 at a time; 
- Westinghouse SMR: 200 MW(e) per reactor with the plan to deploy one or more units individually; and

- Holtec SMR-160: 160 MW(e) per reactor.

All of these near-term SMR designs feature underground siting as well for safety and security reasons. All four vendors presently indicate submitting applications for design certification in the 2014-2015 time range.

For the purposes of this study, the two-unit B\&W mPower SMR is assumed to be the first SMR to be design certified by the U.S. Nuclear Regulatory Commission (NRC). This is based on the selection of the mPower iPWR design for a 5-year cost-share industry partnership by the DOE SMR Licensing Technical Support Program. The two-unit mPower MW(e) output is used to determine the necessary stream flow to supply makeup water for cooling, which is subsequently reflected in the modeling application of the site selection and evaluation criteria. Plant cooling in all cases is assumed to be provided by a closed-cycle mechanical-draft cooling tower with makeup water required for evaporation and blowdown.

\subsection{Energy Demand of Non-DoD Facilities}

The DOE EERE Federal Energy Management Program (FEMP) provided the energy use data for most non-DoD federal facilities. ${ }^{9}$ Past energy use for several sensitive facilities is not reflected in the data. The Compliance Tracking System Data Warehouse provided facility annual detail data for FYs 2009-2012, which were averaged for the purposes of this analysis. Not all non-DoD federal facilities consistently reported energy consumption data. All reported facilities are tracked, but only facilities in the contiguous United States are mapped.

This information was analyzed by postal ZIP code using spatial modeling and GIS. Some facilities utilized a ZIP code unique to that facility and were not spatially represented. In those cases, Google Earth software was used to identify and report the ZIP codes that encompassed the facilities of interest.

The highest energy users among non-DoD federal facilities are the DOE Office of Science national laboratories. High-energy mission-specific facilities (HEMSFs) at the various national laboratories are identified in the Office of Science Composite Sustainability Plan. ${ }^{10}$ In FY 2012, the HEMSFs accounted for $64 \%$ of the energy consumption within the Office of Science. The report notes that a single HEMSF, which includes leadership computing facilities, can consume $95 \%$ of the electricity used at a given site. It is estimated that by FY 2020, HEMSFs will consume 78\% of projected energy consumption within the DOE Office of Science. In FY 2012, the DOE Office of Science consumed just fewer than 2,000,000 MWh of electricity. By FY 2020, based on the sustainability plan, this electricity consumption is projected to grow to approximately 3,250,000 MWh. The current energy usage of these facilities is reflected in the FEMP data.

Energy use at non-DoD facilities is represented in Fig. 2. A calculation of the plant capacity required to meet the current federal facility demand is represented in the figure. Multiple facilities within the same ZIP code are summed. Facilities included in the FEMP data are represented by a colored dot in Fig. 2. The size and the color of the dot indicate the average annual energy consumption within a specific ZIP code for FYs 2009-FY 2012. DOE Office of Science HEMSFs are typically represented by a red or green dot, signifying higher energy consumption among the non-DoD facilities represented. 


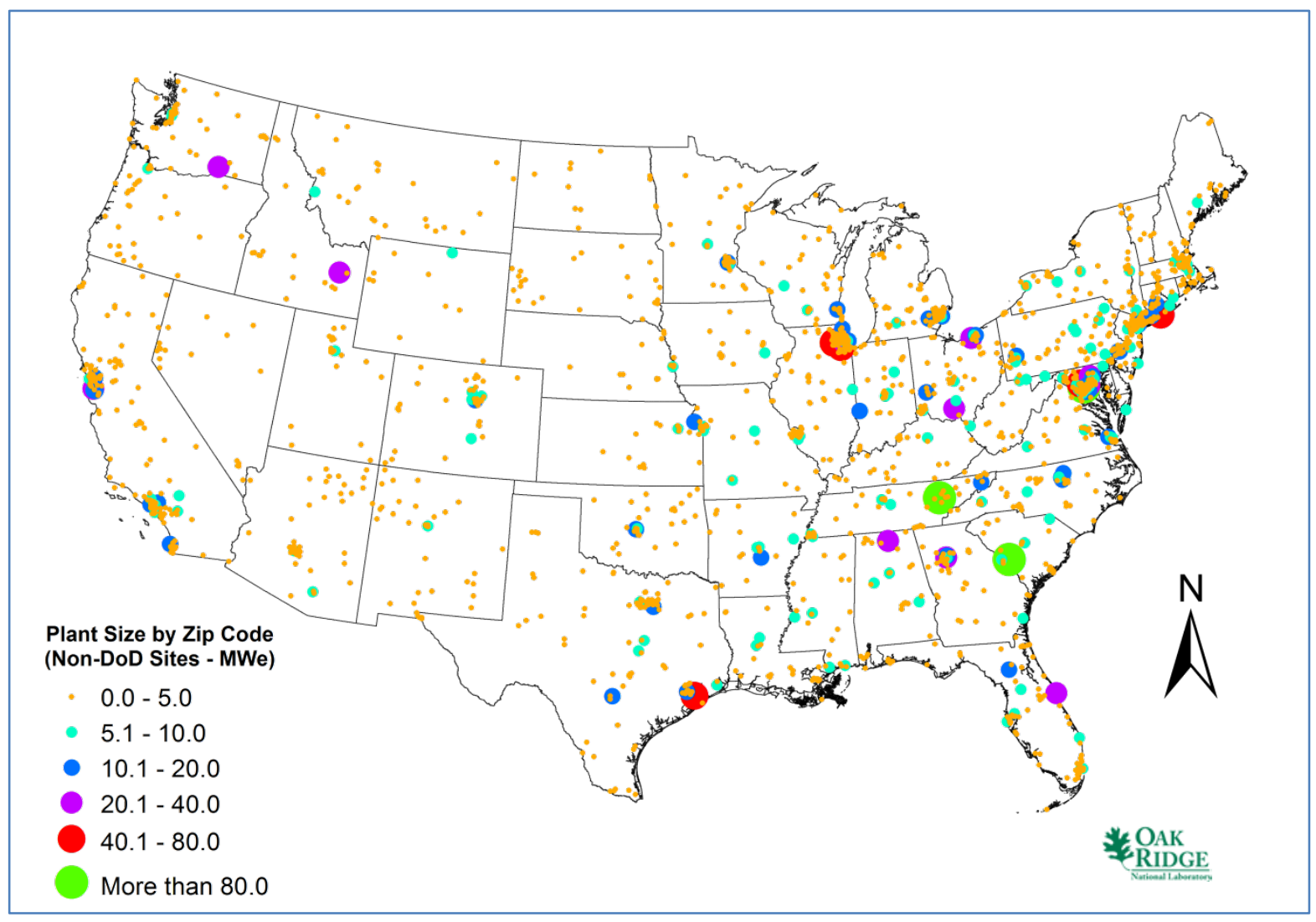

Fig. 2. Energy consumption at reported non-DoD facilities.

As shown in Table 1, the top average reported non-DoD energy consumption occurs in the Washington, DC, area and at numerous national laboratories. A calculation of the plant capacity required to meet the current non-DoD federal facility demand is provided to allow a relative energy consumption comparison between facilities. Required plant capacity to meet current energy demand drops off quickly among nonDoD facility locations from just less than $200 \mathrm{MW}(\mathrm{e})$ to less than $40 \mathrm{MW}(\mathrm{e})$.

Table 1. Top Non-DoD Energy Consumption Locations

\begin{tabular}{|l|c|}
\hline \multicolumn{1}{|c|}{ Location/Facility } & $\begin{array}{c}\text { Plant Capacity to Meet } \\
\text { Energy Demand [MW(e)] }\end{array}$ \\
\hline Washington, DC & 196.9 \\
\hline Bethesda, MD & 177.3 \\
\hline Savannah River Site, GA & 121.4 \\
\hline Oak Ridge National Laboratory, TN & 92.9 \\
\hline Argonne National Laboratory, IL & 64.1 \\
\hline Fermi National Accelerator Laboratory, IL & 57.6 \\
\hline Brookhaven National Laboratory, NY & 55.3 \\
\hline Gaithersburg, MD & 44.5 \\
\hline Johnson Space Center, TX & 40.5 \\
\hline Idaho National Laboratory, ID & 37.8 \\
\hline
\end{tabular}




\subsection{Energy Demand of DoD Facilities}

The DoD Annual Energy Management Report for FY 2011 provided the energy use data for DoD facilities worldwide. ${ }^{11}$ Data for FY 2010 and FY 2011 were provided in the report, which were averaged for the purposes of this analysis. Only data for DoD facilities within the United States were mapped in this analysis. Alaska and Hawaii were included, but not mapped. Foreign DoD facility data were reported but discarded as being outside the scope of the analysis.

As with the non-DoD data provided by FEMP, the DoD data were analyzed by postal ZIP code using spatial modeling and GIS. Some facilities utilized a ZIP code unique to that facility and were not spatially represented. In those cases, Google Earth software was used to identify the ZIP code that encompassed the facility of interest. Reserve force energy consumption was reported at a state level. Since this could not be attributed to any specific ZIP code location, these data were omitted.

The DoD Energy Management Report notes that the DoD manages over 500 installations worldwide. DoD facility energy consumption, as opposed to operational energy consumption (operational energy consumption includes vehicle, aviation, and ship fuel), represents $20-25 \%$ of DoD total energy costs but accounts for approximately $40 \%$ of the greenhouse gas emissions. In addition, critical DoD mission assurance is dependent on an aging and vulnerable power grid. Therefore, the Energy Management Report asserts that the DoD energy strategy includes reducing energy cost and improving energy security. One element of this plan includes leveraging advanced technology, which would include the use of SMRs to meet federal clean energy goals.

Energy use at DoD facilities is represented in Fig. 3. A calculation of the plant capacity required to meet the current federal facility demand is represented in the figure. Multiple facilities within the same ZIP code are summed. Facilities included in the energy report data are represented by a colored dot in Fig. 3. The size and the color of the dot indicate the average annual energy consumption within a specific ZIP code for FY 2010 and FY 2011. While there are many more individual facilities $(\sim 4,800)$ in the non-DoD facility dataset, there are more facilities with relatively large energy consumption in the DoD facility dataset. Table 2 identifies the locations where the top reported DoD facility average energy consumption occurs. As shown in Table 2 , required plant capacity to meet current DoD facility energy demand drops off much more slowly among the top energy-consuming facilities [from $120 \mathrm{MW}(\mathrm{e})$ to more than $80 \mathrm{MW}(\mathrm{e})]$ than a comparative list of non-DoD facilities in Table 1. 


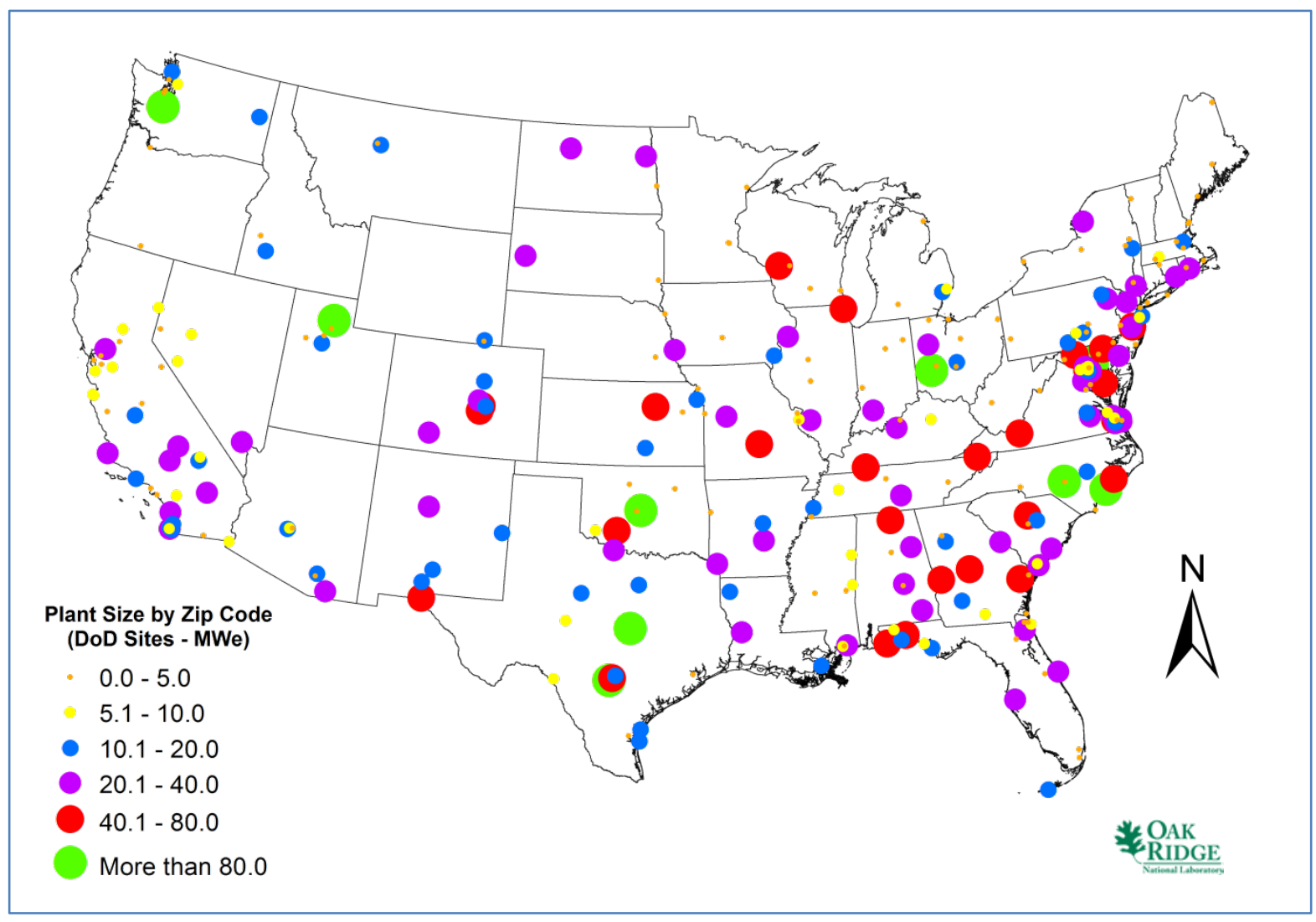

Fig. 3. Energy consumption at reported DoD facilities.

As shown in Table 2, the top reported DoD average energy consumption occurs west of the Mississippi River in Oklahoma. Two of the highest energy-consuming locations are near Fairbanks, Alaska, which is not mapped in this evaluation. A calculation of the plant capacity required to meet the current DoD federal facility demand is shown to provide for a relative energy consumption comparison between facilities.

Table 2. Top DoD Energy Consumption Locations

\begin{tabular}{|l|c|}
\hline \multicolumn{1}{|c|}{ Location/Facility } & $\begin{array}{c}\text { Plant Capacity to Meet } \\
\text { Energy Demand [MW(e)] }\end{array}$ \\
\hline Tinker AFB, OK & 120.1 \\
\hline Fort Bragg, NC & 118.1 \\
\hline Wright-Patterson AFB, OH & 107.7 \\
\hline Fort Meade, MD & 106.6 \\
\hline Camp Lejeune, NC & 105.0 \\
\hline Fort Wainwright, AK & 101.4 \\
\hline Eielson AFB, AK & 84.6 \\
\hline Fort Lewis, WA & 83.5 \\
\hline Fort Hood, TX & 83.4 \\
\hline Hill AFB, UT & 82.9 \\
\hline
\end{tabular}




\subsection{Combined Energy Demand of Federal Facilities}

The non-DoD and the DoD federal energy consumption datasets were combined and summed by ZIP code. The resulting combined energy consumption map is shown in Fig. 4. By visual analysis of Fig. 4, it can be seen that the majority of federal facilities with high energy consumption reside east of the Mississippi River. Some of the visual clutter has been removed by filtering out facilities with an energy consumption of less than $1 \mathrm{MW}(\mathrm{e})$ in equivalent plant capacity.

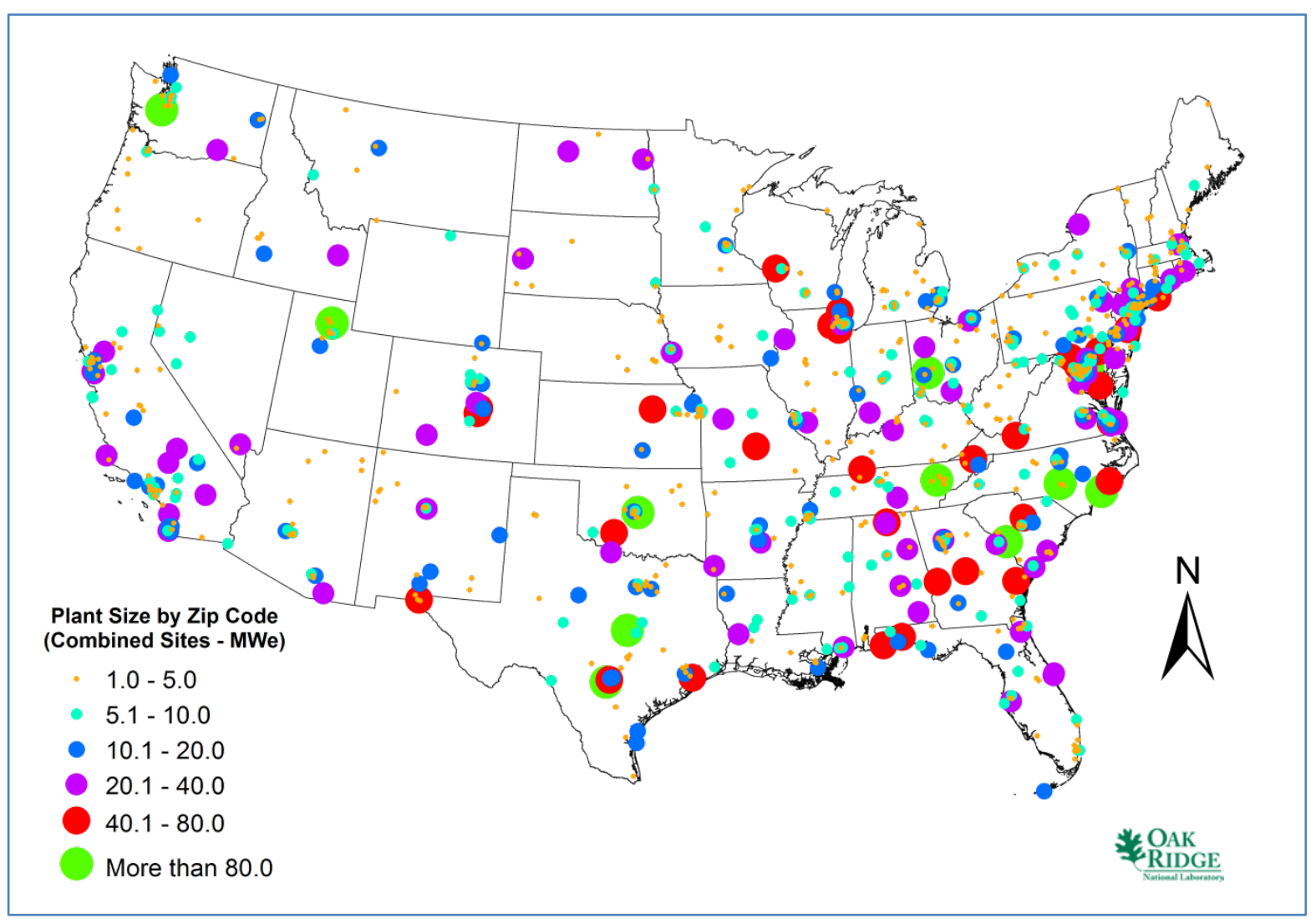

Fig. 4. Energy consumption at reported DoD and non-DoD facilities.

The energy consumption maps were prepared on a regional basis to provide more clarity, samples of which are shown in Fig. 5 and Fig. 6. Federal energy clusters can be visualized at this scale, including the Hampton Roads area. Other possible federal energy clusters visible include the Washington, DC area; Long Island and upper New Jersey; Chicago; eastern North Carolina; central South Carolina; the Florida Panhandle, and possibly southeastern Alabama and southwestern Georgia; and east Tennessee. Utilizing Fig. 4, federal energy clusters may also be visualized in south central Texas, central Oklahoma, Colorado, southern California, and western Washington. 


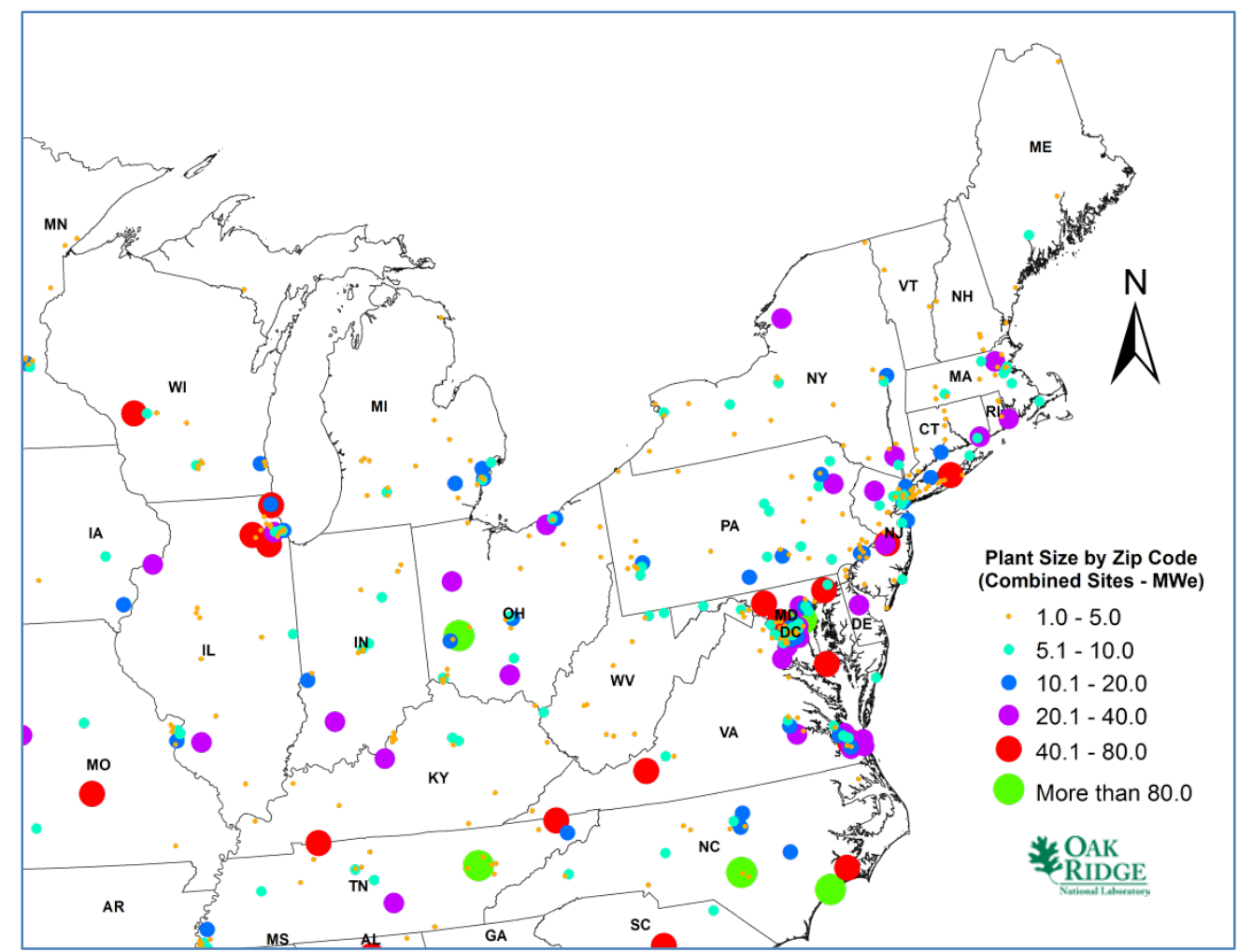

Fig. 5. Combined federal energy consumption in the Northeast.

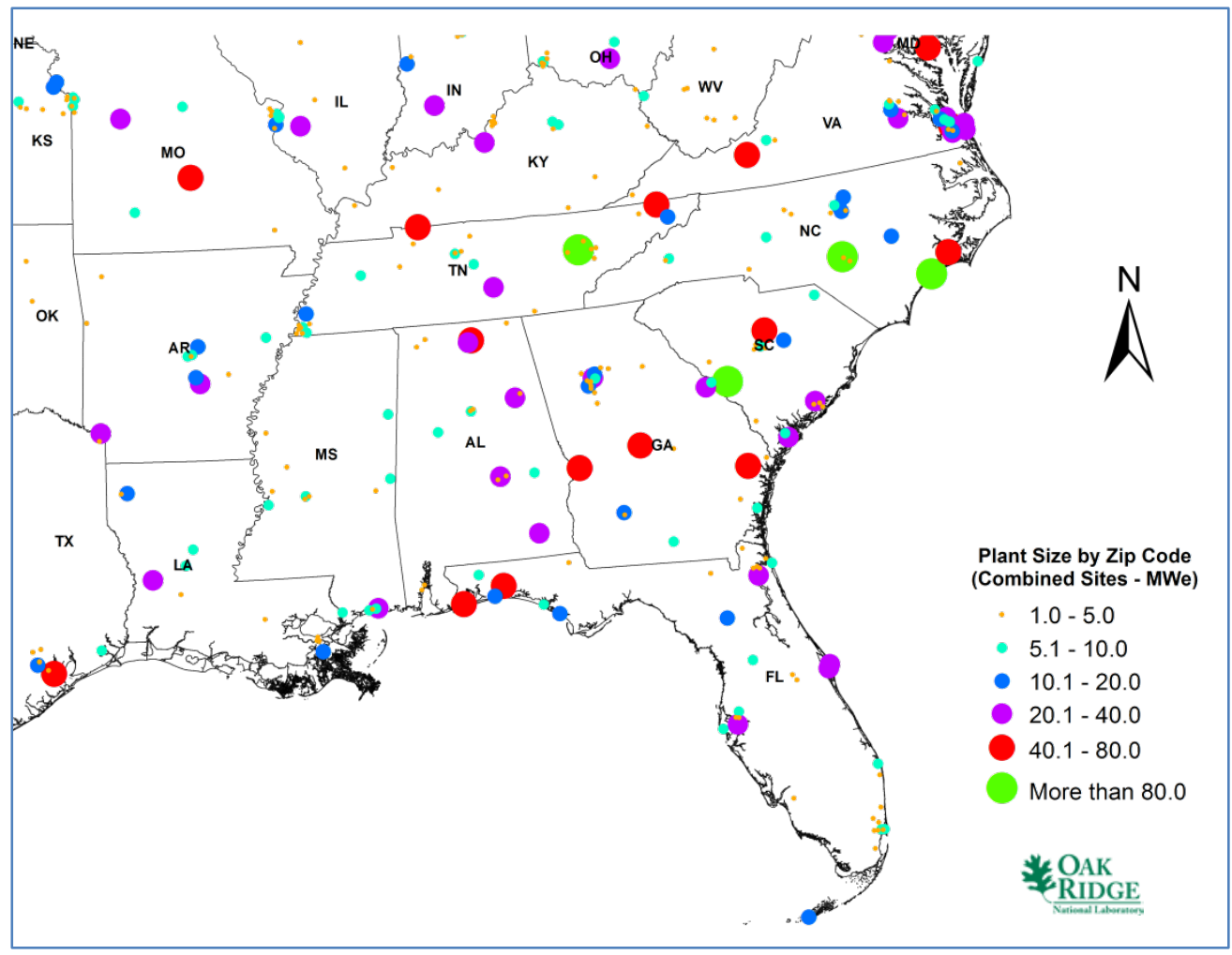

Fig. 6. Combined federal energy consumption in the Southeast. 
A different perspective of the combined federal energy data is provided in Fig. 7. This figure shows the combined federal energy consumption summed and binned by state. The light blue, dark blue, and green colored states have higher federal energy consumption and may warrant further investigation to identify potential energy clusters. The upper Northeast has low federal energy consumption. Likewise, most of the states west of the Mississippi River have lower federal energy consumption, except for Washington, California, Colorado, Oklahoma, and Texas.

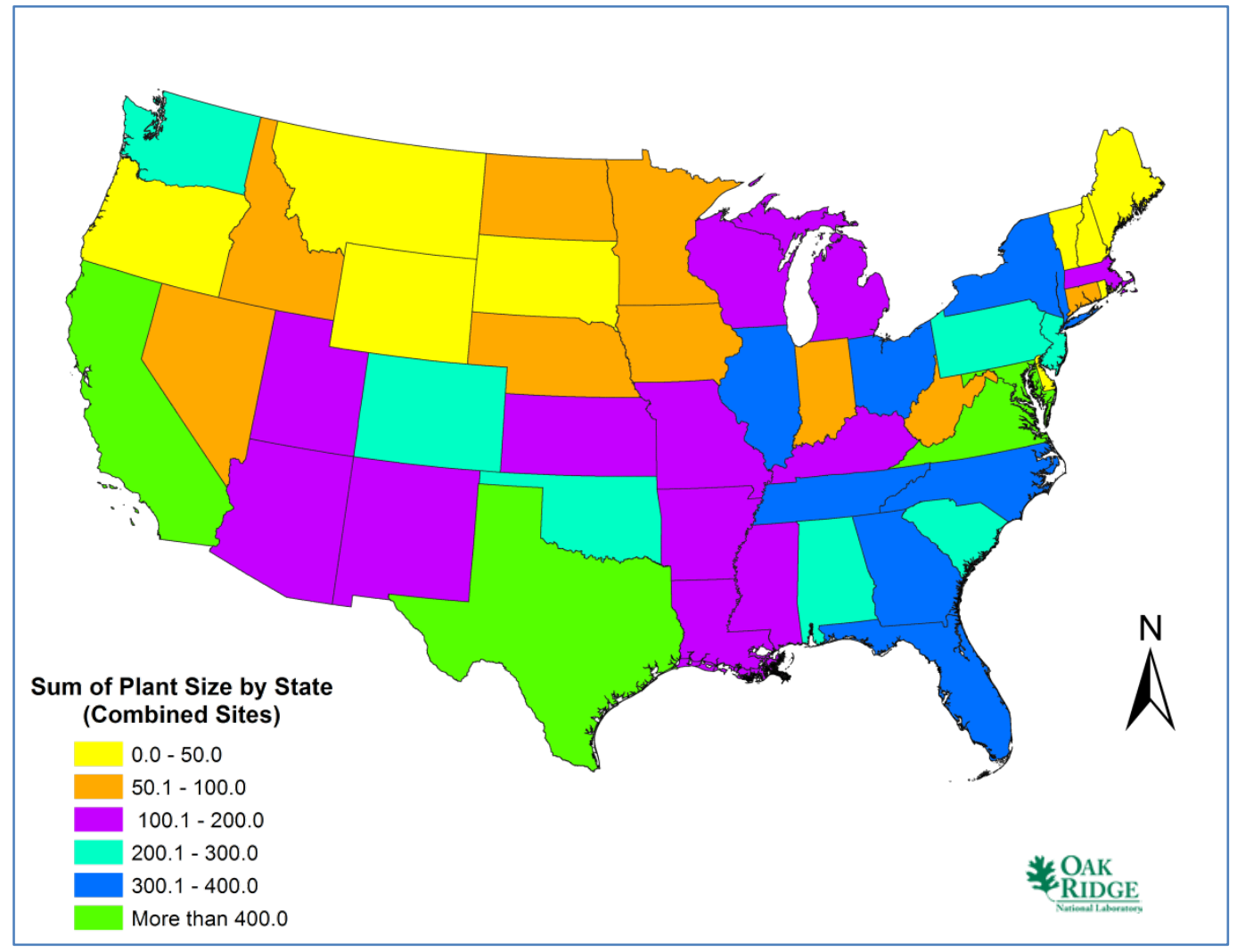

Fig. 7. Combined federal energy consumption summed by state.

The postal ZIP code system breaks the country into 99 "mostly" contiguous areas, as shown in Fig. 8. These areas are identified by the first two digits of the ZIP code. The combined federal energy data were sorted by the first two digits of the ZIP code, binned, and plotted, as shown in Fig. 9. In Fig. 9, the orange (gold), dark blue, and red colored states have higher federal energy consumption. For clarity, the only dark blue areas are in Virginia, North Carolina, and Washington. This depiction allows clustered areas within state boundaries to be more obvious, as well as potential multi-state areas. Note that eastern Washington, which is in dark blue, shares the same two-digit ZIP code area (99) as all of Alaska. The dark blue color in eastern Washington is a result of the power demand in Alaska. Much of the country in Fig. 9 is binned into the lower energy consumption categories shown in light blue and purple. 


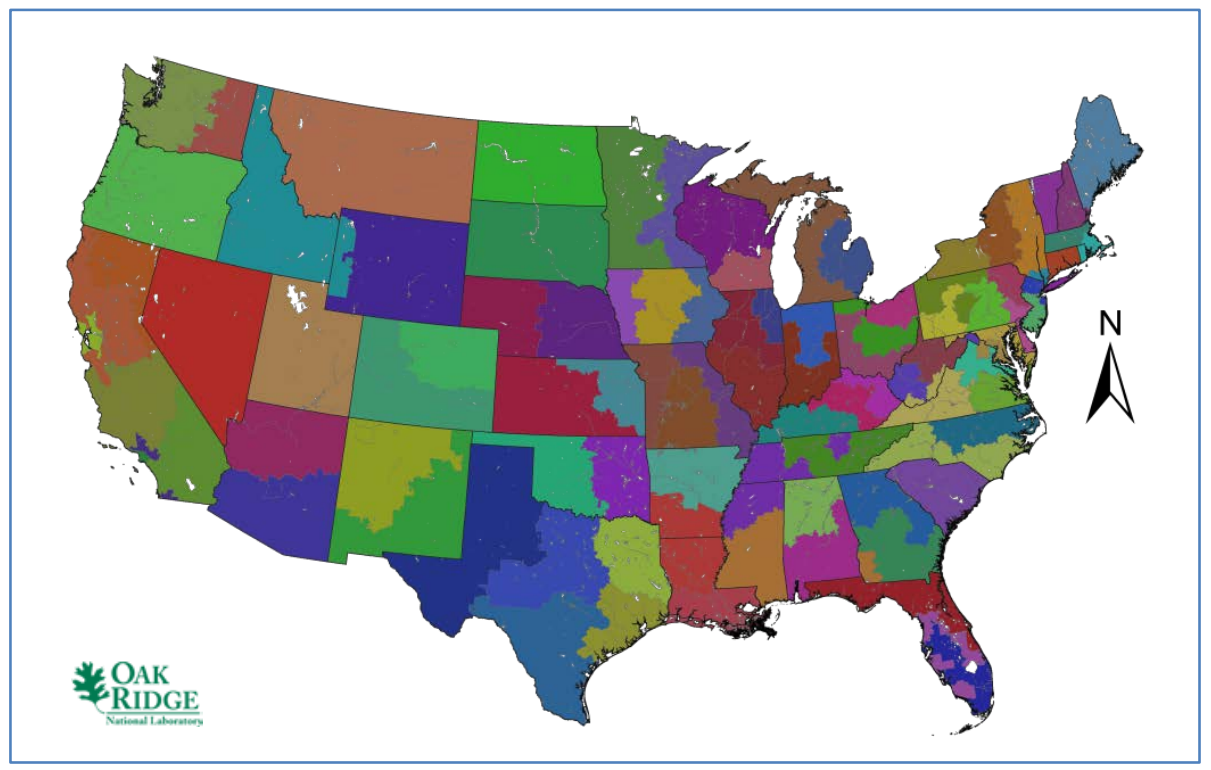

Fig. 8. Two-digit ZIP code clusters.

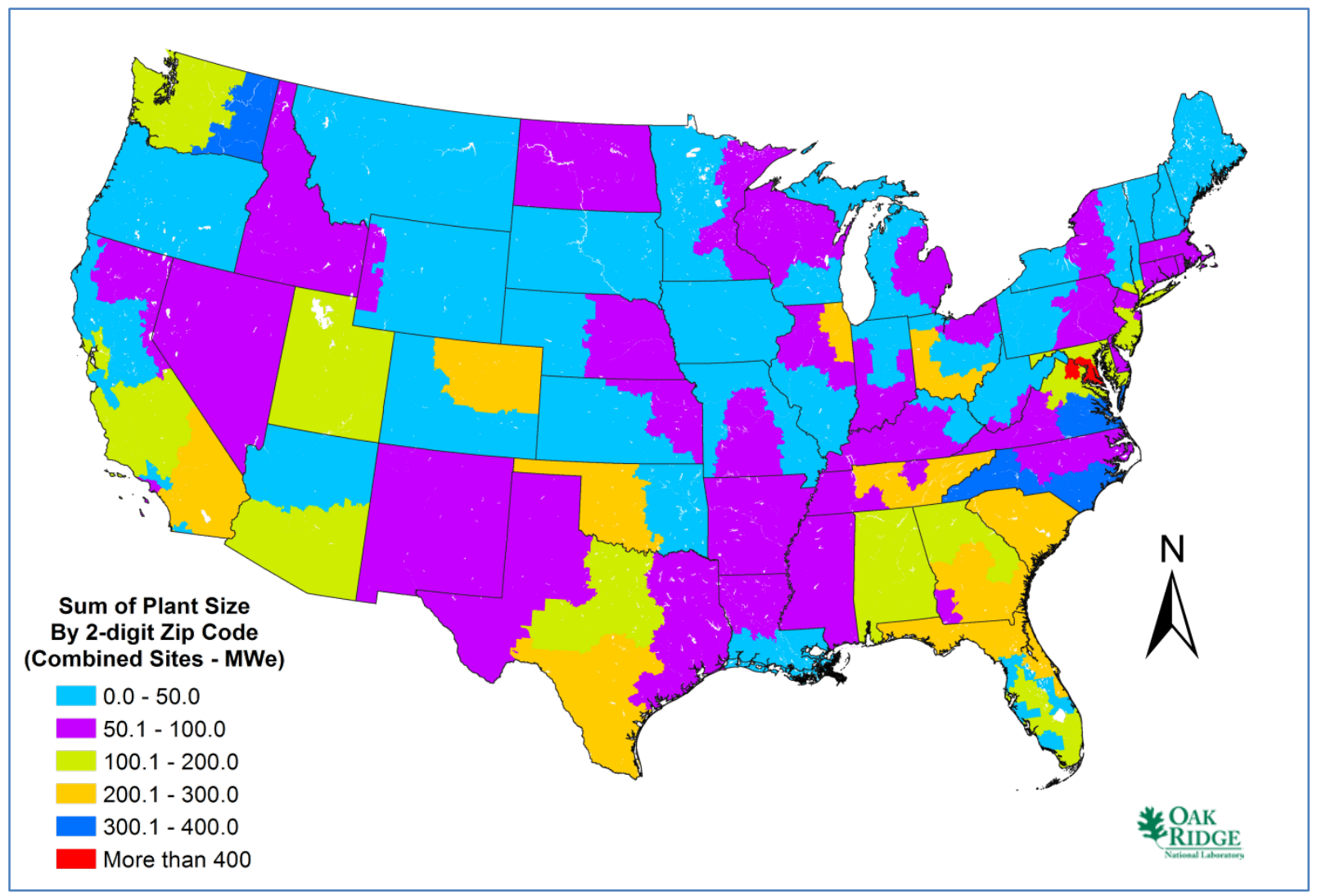

Fig. 9. Combined federal energy consumption by two-digit ZIP code area.

Table 3 identifies the top 10 two-digit ZIP code areas by federal energy consumption. This is a straightforward calculation of all federal energy demand within a given two-digit ZIP code (XXуyy) area. These areas represent possible federal energy clusters where an SMR could potentially be utilized to meet the area energy demands. Alaska is included in the list; however, Alaska has not been evaluated using the 
OR-SAGE tool for SMR siting. A calculation of the plant capacity required to meet the current federal facility demand is shown to provide for a relative energy consumption comparison between facilities.

In the two-digit ZIP code calculation, possible cross-state or cross-ZIP code clusters are overlooked. Also, some two-digit ZIP code areas are relatively small. Therefore, a visual analysis of the data was also conducted to identify other possible federal energy clusters, often using a larger map polygon to visualize a cluster. Assuming larger cluster areas can be accommodated, Table 4 identifies the top federal energy cluster areas using visual analyses. The plant capacity values in Table 4 are based a hand calculation of local facilities with a projected plant capacity to meet an annual energy need above 5 MW(e) to simplify the visual calculation. Therefore, the stated capacity of similar areas in Table 3 and Table 4 will not match exactly.

Table 3. Top Combined Federal Energy Consumption Locations by Two-Digit ZIP Code

\begin{tabular}{|l|c|c|}
\hline \multicolumn{1}{|c|}{ Location/Facility } & $\begin{array}{c}\text { Plant Capacity to Meet } \\
\text { Energy Demand [MW(e)] }\end{array}$ & $\begin{array}{c}\text { Percentage of Federal } \\
\text { Energy Demand }\end{array}$ \\
\hline Washington DC & 919.7 & $9.3 \%$ \\
\hline Virginia Peninsula/Hampton Roads area & 368.5 & $3.7 \%$ \\
\hline Alaska \& Eastern Washington & 363.3 & $3.7 \%$ \\
\hline Eastern North Carolina & 303.6 & $3.1 \%$ \\
\hline Chicago, Illinois & 285.7 & $2.9 \%$ \\
\hline Western South Carolina/SRS & 274.0 & $2.8 \%$ \\
\hline Florida Panhandle & 265.3 & $2.7 \%$ \\
\hline Southern California & 247.5 & $2.5 \%$ \\
\hline Denver-Colorado Springs, Colorado & 237.8 & $2.4 \%$ \\
\hline East Tennessee/ORNL & 234.3 & $2.4 \%$ \\
\hline
\end{tabular}

Table 4. Top Combined Federal Energy Consumption Locations by Visual Analysis

\begin{tabular}{|l|c|c|}
\hline \multicolumn{1}{|c|}{ Location/Facility } & $\begin{array}{c}\text { Plant Capacity to Meet } \\
\text { Energy Demand [MW(e)] }\end{array}$ & $\begin{array}{c}\text { Percentage of Federal } \\
\text { Energy Demand }\end{array}$ \\
\hline Washington, DC & 881.0 & $8.9 \%$ \\
\hline Long Island - Northern New Jersey & 342.0 & $3.5 \%$ \\
\hline South Carolina - SRS area in Georgia & 337.1 & $3.4 \%$ \\
\hline Eastern North Carolina & 334.3 & $3.4 \%$ \\
\hline Hampton Roads area of Virginia & 328.9 & $3.3 \%$ \\
\hline $\begin{array}{l}\text { North Florida-Southeast Alabama - } \\
\text { Southwest Georgia }\end{array}$ & 304.9 & $3.1 \%$ \\
\hline Southern California & 300.1 & $3.0 \%$ \\
\hline San Antonio-Austin Texas & 252.0 & $2.6 \%$ \\
\hline Chicago, Illinois area & 247.1 & $2.5 \%$ \\
\hline Central Colorado & 226.1 & $2.3 \%$ \\
\hline Southwest Oklahoma - North Texas & 218.8 & $2.2 \%$ \\
\hline Western Ohio & 206.1 & $2.1 \%$ \\
\hline East Tennessee & 183.8 & $1.9 \%$ \\
\hline
\end{tabular}




\subsection{Federal Energy Clusters Relative to SMR Candidate Areas}

The total federal energy demand, based on reported data, is 9,876.7 MW(e) (equivalent plant capacity). A single mPower iPWR has a nameplate capacity of $180 \mathrm{MW}(\mathrm{e})$, though the standard plant design is for a two-reactor pack with a nameplate capacity of $360 \mathrm{MW}(\mathrm{e})$. Except for the Washington, DC area, the federal facility energy clusters identified range from approximately 2\% [ 200 MW(e)] of the reported total federal energy consumption to approximately 4\% [ 400 MW(e)] of the reported total energy consumption. The largest reported energy demand at any single facility is approximately $120 \mathrm{MW}(\mathrm{e})$ in equivalent plant capacity. Based on current design information, this is below the output of a single mPower reactor at $180 \mathrm{MW}(\mathrm{e})$ and well below the standard two-unit mPower design rated at $360 \mathrm{MW}(\mathrm{e})$. Therefore, if a small reactor is to be included in the energy mix to provide power to meet federal clean energy goals, then it makes sense to look at clustered facilities. Micro-grids and grid security issues associated with clustered facilities are not analyzed in this report.

A brief review of several candidate federal energy cluster areas is provided in the remainder of Section 2.4. The reviews are not presented in any ranked order; instead, they are presented in a geographical rotation from east to west and north to south. Polygons inserted on some of the analysis figures are intended to highlight the facilities to be clustered. The polygon shape and size is not intended to relay any other informational detail. The potential federal energy cluster sites are overlaid onto an SMR candidate area map generated by OR-SAGE. It should be noted that the OR-SAGE candidate siting area maps are generated using specified threshold values for the various SMR siting parameters, which can be varied to produce alternate SMR candidate area depictions. The SMR population site evaluation criterion has not been included in any of the figures in this section because SMR siting sensitivity to population density will be explored in a follow-on task to this project. The size of the emergency planning zone associated with an SMR is a topic that is being explored between SMR vendors and the NRC. If the size of the emergency planning zone is eventually reduced for SMRs, then the importance of the population density in the set of SMR siting criteria is diminished. Therefore, there is interest in exploring the sensitivity of SMR siting potential to varying population density. In particular, SMR siting sensitivity to population density in the Hampton Roads area will be evaluated.

\subsubsection{Long Island Area Summary}

The Long Island, New York, and northern New Jersey area is shown in Fig. 10. Federal facilities are identified by a dot relative in size and color to the equivalent plant capacity for the collective federal facilities in a given ZIP code area. The land mass is identified by black shoreline. The Long Island Sound is northwest of Long Island, and the Atlantic Ocean is southeast of Long Island in Fig. 10. The Hudson River flows from north to south in the eastern portion of Fig. 10, emptying into Upper New York Bay west of Manhattan, which has a large concentration of federal facilities. Areas in green on the map indicate those areas where the SMR siting criteria are met completely without consideration for surrounding population based on a previous study on SMR siting. ${ }^{12}$ Areas in white on the map are those where at least one SMR siting criterion (not including population) is not met at the threshold evaluated in the SMR siting report. For example, much of the area close to Manhattan is white because it is excluded as a hazardous area due to all the nearby commercial airports, or it is classified as protected land. Long Island is largely excluded due to inadequate stream flow to provide makeup water for closed cycle cooling. There is significant area toward Connecticut and New Jersey in Fig. 10 where SMR siting is favorable pending an evaluation of population. In fact, dense population in this area may preclude consideration of this region for SMR placement. As shown, these surrounding areas would provide candidates for a reactor site to service the numerous federal facilities in the vicinity. However, it should be noted that this is a fairly broad federal energy cluster; for reference, Long Island is approximately 
115 miles long. Therefore, long transmission infrastructure would be required to service all facilities in the cluster.

Note that a change in the SMR siting criteria threshold values will alter the SMR candidate area. Also, the use of once-through ocean cooling or an air-cooled system versus limiting the evaluation to cooling water makeup from available stream flow to a closed cycle cooling system, as in this evaluation, would impact the analysis. Criterion such as landslide hazard or slope that may limit the positive projection of SMR candidate areas may subsequently be addressed through site-specific evaluations. In other words, the OR-SAGE tool used to provide the SMR candidate area analysis offers a static look at a dynamic process. This is true for each of the cluster summaries in this section.

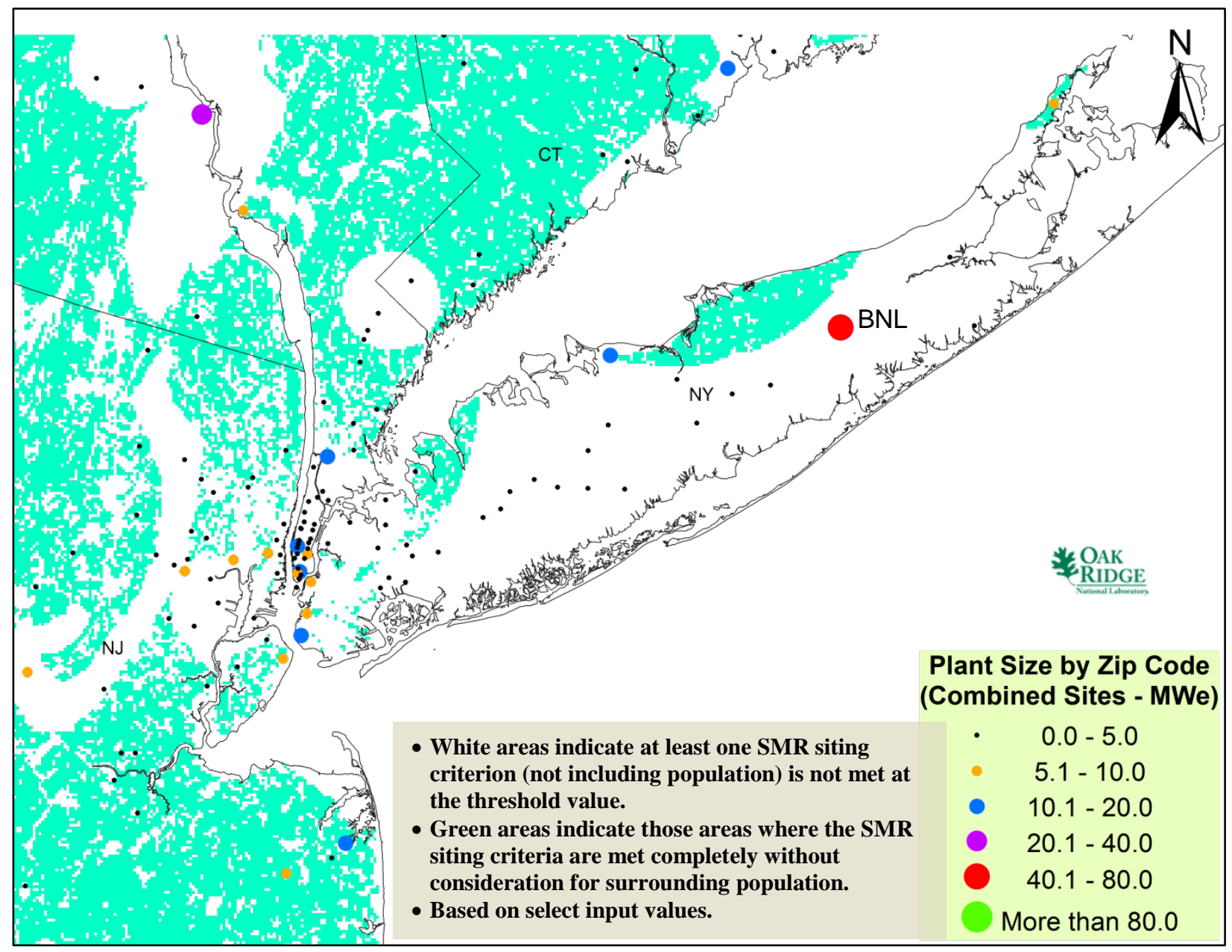

Fig. 10. Long Island, New York area relative to SMR siting criteria. 


\subsubsection{Washington, DC, Summary}

The Washington, DC, area is shown in Fig. 11. Federal facilities are identified by a dot relative in size and color to the equivalent plant capacity for the collective federal facilities in a given ZIP code area. Rivers are identified by black shoreline. The Potomac River is visible flowing from the west to the south in Fig. 11. The Anacostia River is also clearly visible flowing north to south meeting the Potomac River in the center of Fig. 11. The boundary of the District of Columbia is outlined. Virginia is southwest of the Potomac River, and the remaining land mass shown is in Maryland. Areas in green on the map indicate those areas where SMR siting criteria are met completely without consideration for surrounding population. Areas in white on the map are areas where at least one SMR siting criterion (not including population) is not met at the threshold evaluated in the SMR siting report. For example, the Potomac River is white because it is excluded as wetlands and open water. Areas along the river shoreline may be excluded as being in the 100-year floodplain, having landslide hazard issues, having slope issues, or being part of protected land. Areas in the metropolitan areas on the map do not meet the SMR siting thresholds evaluated for hazardous facilities, which includes military bases, and protected lands. These areas will likely not meet the population thresholds evaluated in the previous SMR siting report as well. In fact, population is a significant issue extending well beyond the Capital Beltway. However, there are significant areas to the east and west in Fig. 11 where SMR siting is favorable, pending further analysis of population. These offset areas would provide for a reactor site to service the numerous federal facilities in the larger surrounding area.

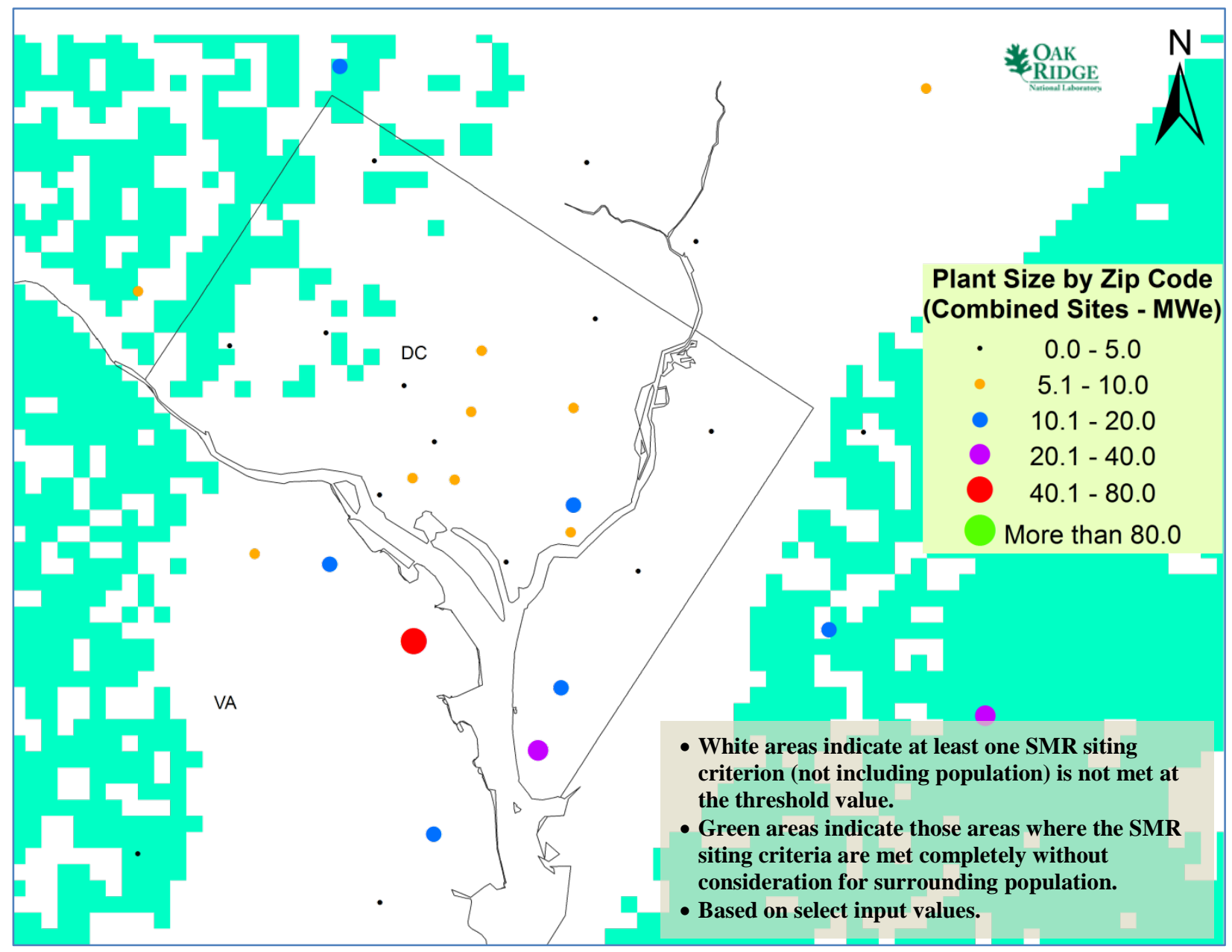

Fig. 11. Washington, DC, area relative to SMR siting criteria. 


\subsubsection{Hampton Roads Summary}

The Norfolk-Hampton Roads area is shown in Fig. 12. Federal facilities are identified by a dot relative in size and color to the equivalent plant capacity for the collective federal facilities in a given ZIP code area. The land mass is identified by black shoreline. The James River is visible in the center western portion of Fig. 12. The Elizabeth River and the Nansemond River are also clearly visible meeting the James River in the center of Fig. 12. The York River is in the upper western portion of the figure, and the entrance to the Chesapeake Bay is in the central eastern portion of the figure. Areas in green on the map indicate those areas where SMR siting criteria are met completely without consideration for surrounding population. Areas in white on the map are areas where at least one SMR siting criterion (not including population) is not met at the threshold evaluated in the SMR siting report. For example, the James River is white because it is excluded as wetlands and open water. Areas along the river shoreline may be excluded as being in the 100-year floodplain, having landslide hazard issues, having slope issues, or being part of protected land. The white area in the southern central portion of Fig. 12 is protected land in the Great Dismal Swamp National Wildlife Refuge. Areas in downtown Newport News, Hampton, and Norfolk do not meet the SMR siting thresholds evaluated for hazardous facilities, which includes military bases, and protected lands. These areas will likely not meet the population thresholds evaluated in the previous SMR siting report as well. However, there are significant areas within Norfolk and Portsmouth and around the Elizabeth River, the Nansemond River, and the James River where SMR siting is favorable, pending further analysis of population. These central areas would provide for a reactor site to service the numerous federal facilities in this area.

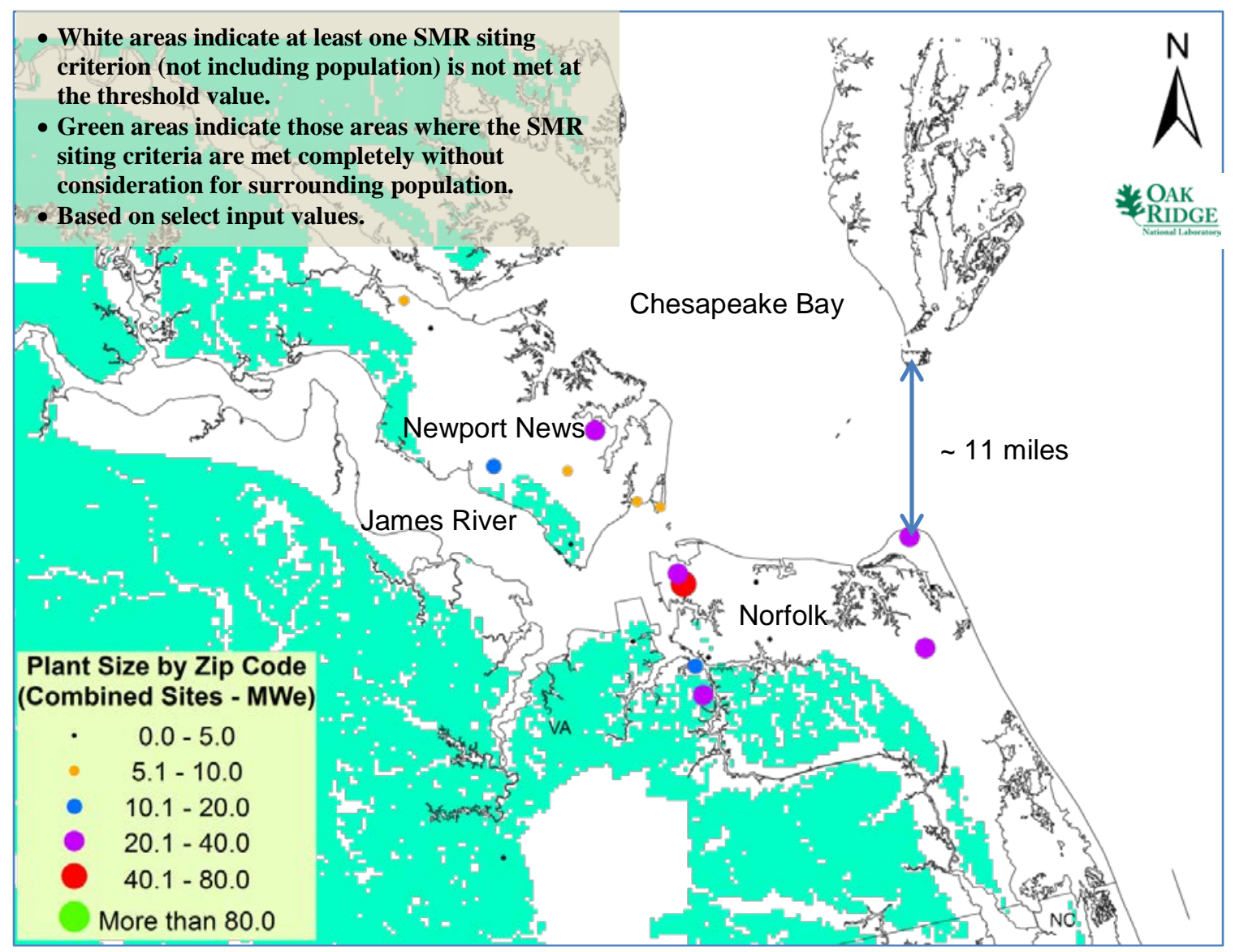

Fig. 12. Hampton Roads area relative to SMR siting criteria. 


\subsubsection{Eastern North Carolina Summary}

The eastern North Carolina area is shown in Fig. 13. Federal facilities are identified by a dot relative in size and color to the equivalent plant capacity for the collective federal facilities in a given ZIP code area. The land mass is identified by black shoreline. The Albemarle Sound and the Pamlico Sound are visible to the east in Fig. 13. Areas in green on the map indicate those areas where SMR siting criteria are met completely without consideration for surrounding population. Areas in white on the map are areas where at least one SMR siting criterion (not including population) is not met at the threshold evaluated in the SMR siting report. For example, the North Carolina Outer Banks and inland shoreline are white because they are excluded as wetlands and open water, protected land, or within the 100-year floodplain. The large white circles are commercial airports associated with larger cities. The large white space in the west on the map is associated with moderate and high landslide hazards. The dotted oval is a possible federal energy cluster extending approximately 100 miles from Fort Bragg east to Camp Lejeune. There is significant area within the oval where SMR siting would be favorable. However, siting an SMR at one of the major energy consumption facilities would require long transmission infrastructure to service the remaining facilities in the cluster because most facilities are located on the fringe of the oval.

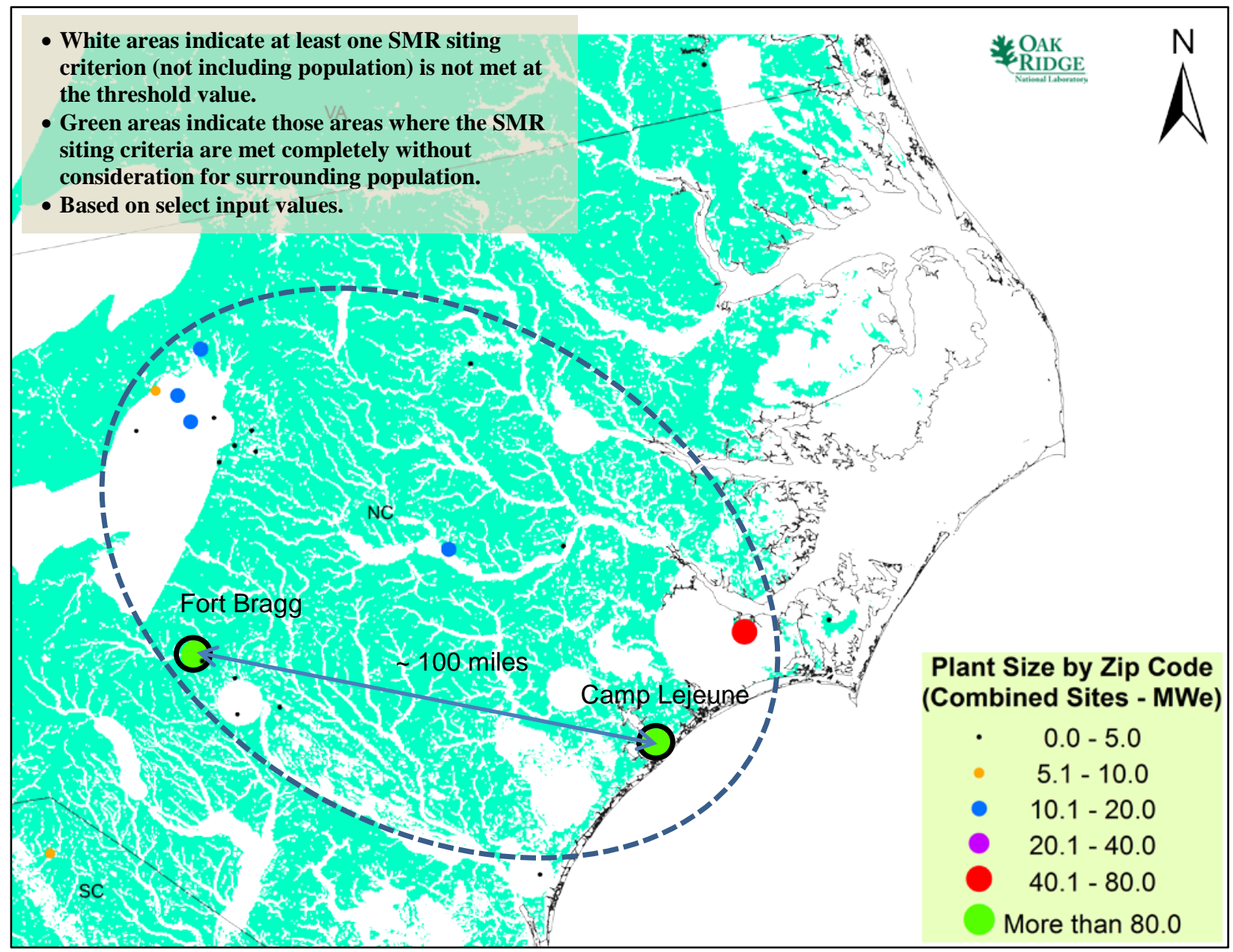

Fig. 13. Eastern North Carolina area relative to SMR siting criteria. 


\subsubsection{South Carolina and Eastern Georgia Summary}

Area in South Carolina and eastern Georgia is shown in Fig. 14. Federal facilities are identified by a dot relative in size and color to the equivalent plant capacity for the collective federal facilities in a given ZIP code area. The land mass is identified by black shoreline. For reference, Charleston, South Carolina, is located at the northeastern-most purple dot in Fig. 14. Areas in green on the map indicate those areas where SMR siting criteria are met completely without consideration for surrounding population. Areas in white on the map are areas where at least one SMR siting criterion (not including population) is not met at the threshold evaluated in the SMR siting report. For example, the area surrounding Charleston is white because it is excluded as wetlands or it exceeds the safe shutdown earthquake threshold. The large white circles are commercial airports associated with larger cities. There is significant area across Fig. 14 where SMR siting is favorable for a reactor site to service the numerous federal facilities in the larger surrounding vicinity. However, it should be noted that this is a fairly broad federal energy cluster; approximately 130 miles separates Charleston and Augusta, Georgia, near the Savannah River Site, represented by the large green dot. A smaller, more compact federal energy cluster centered at the Savannah River Site is also a possibility.

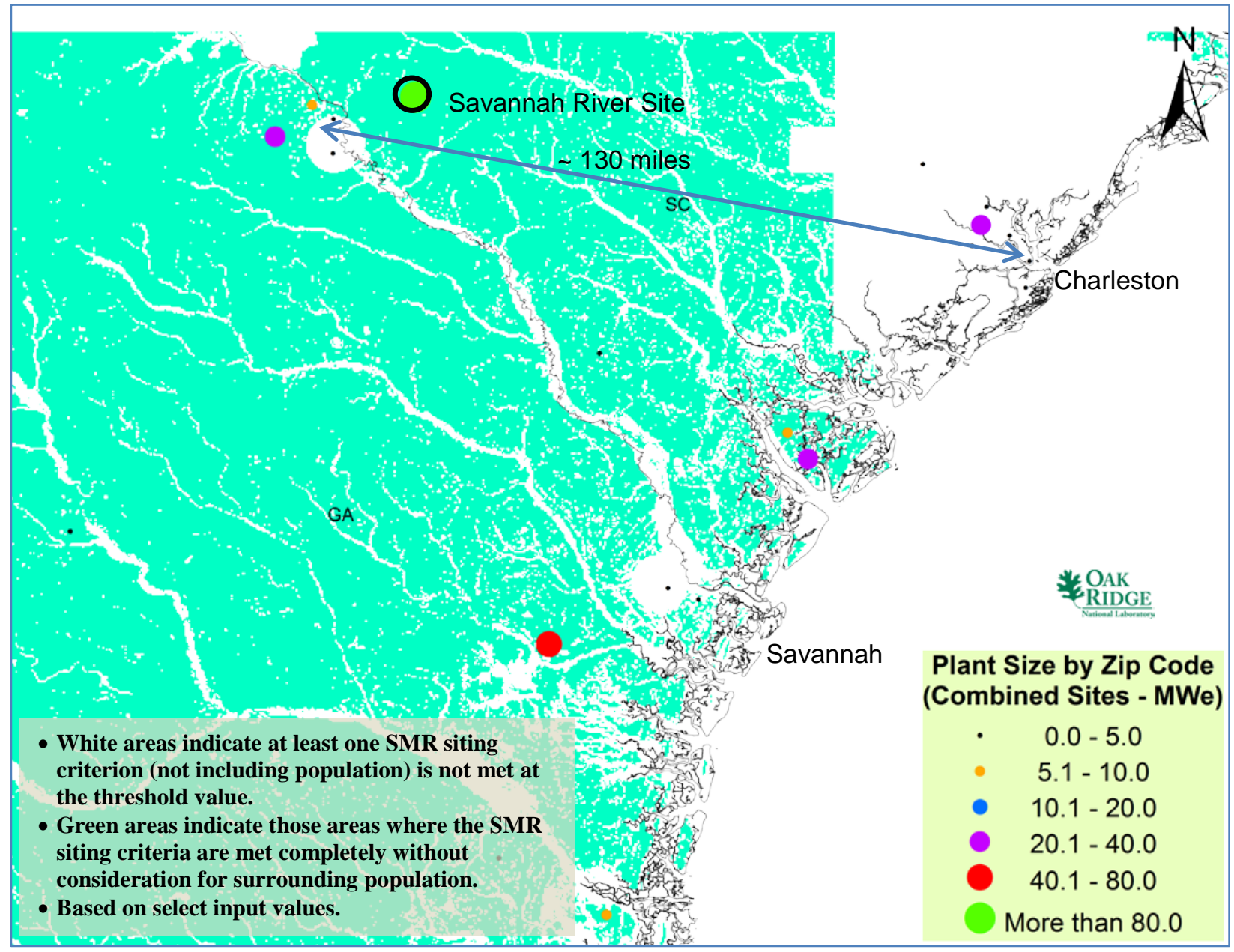

Fig. 14. South Carolina and eastern Georgia area relative to SMR siting criteria. 


\subsubsection{Florida Panhandle, Southeastern Alabama, and Southwestern Georgia Summary}

Area in the Florida Panhandle, southeastern Alabama, and southwestern Georgia is shown in Fig. 15. Federal facilities are identified by a dot relative in size and color to the equivalent plant capacity for the collective federal facilities in a given ZIP code area. The land mass is identified by black shoreline. For reference, Pensacola, Florida, is located in the vicinity of the western-most red dot in Fig. 15 along the Gulf Coast, and Fort Walton Beach is located in the vicinity of the red dot on the Florida Panhandle just to the east of Pensacola. Areas in green on the map indicate those areas where SMR siting criteria are met completely without consideration for surrounding population. Areas in white on the map are those where at least one SMR siting criterion (not including population) is not met at the threshold evaluated in the SMR siting report. For example, the large white area on the Gulf Coast, just east of Panama City, is excluded as wetlands, in the 100-year floodplain, or is protected land as part of the Apalachicola National Forest. The large white circles are commercial airports associated with larger cities. There is significant area across Fig. 15 where SMR siting is favorable. These areas would provide an area for an SMR site to service the numerous federal facilities in the larger three-state area, or just in the more compact western Florida Panhandle vicinity. It should be noted that the larger three-state area would constitute a fairly broad federal energy cluster. Approximately 160 miles separate Fort Walton Beach, Florida, and Fort Benning, Georgia, represented by the northern-most red dot.

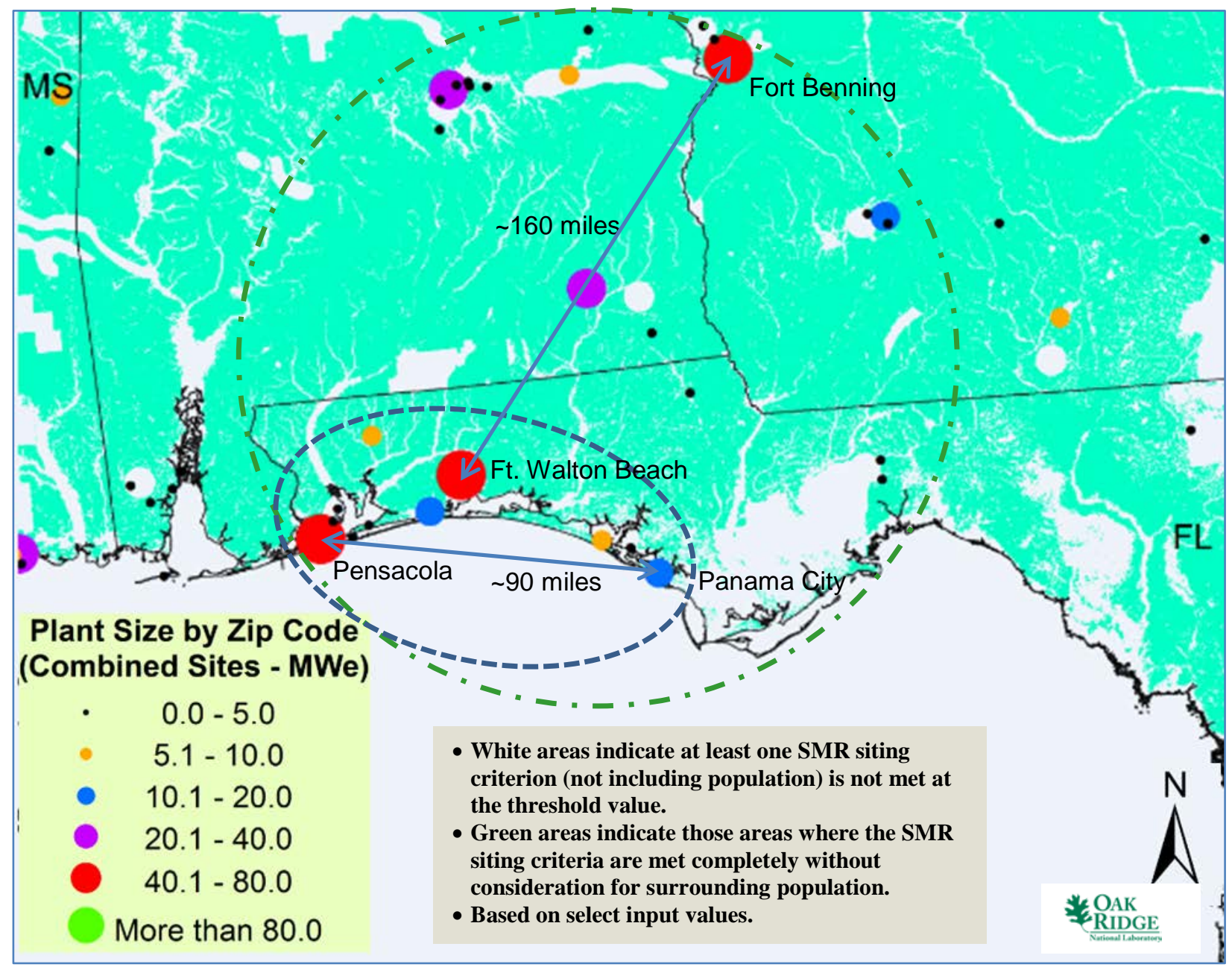

Fig. 15. Florida Panhandle, Alabama, and Georgia area relative to SMR siting criteria. 


\subsubsection{Western Ohio Summary}

The western Ohio area is shown in Fig. 16. Federal facilities are identified by a dot relative in size and color to the equivalent plant capacity for the collective federal facilities in a given ZIP code area. Areas in green on the map indicate those areas where SMR siting criteria are met completely without consideration for surrounding population. Areas in white on the map are those where at least one SMR siting criterion (not including population) is not met at the threshold evaluated in the SMR siting report. For example, the Little Miami River flowing south into the Ohio River at the Ohio-Kentucky border is white because it is excluded as wetlands and open water. Areas along the river shoreline may be excluded as being in the 100-year floodplain, having landslide hazard issues, having slope issues, or being part of protected land. The large white circles are commercial airports associated with larger cities. Wright-Patterson Air Force Base is represented by the large green dot in Fig. 16. The dotted triangle is a possible federal energy cluster extending approximately 60 miles to the east to Columbus and 60 miles north to Lima. There is significant area within the triangle where SMR siting would be favorable.

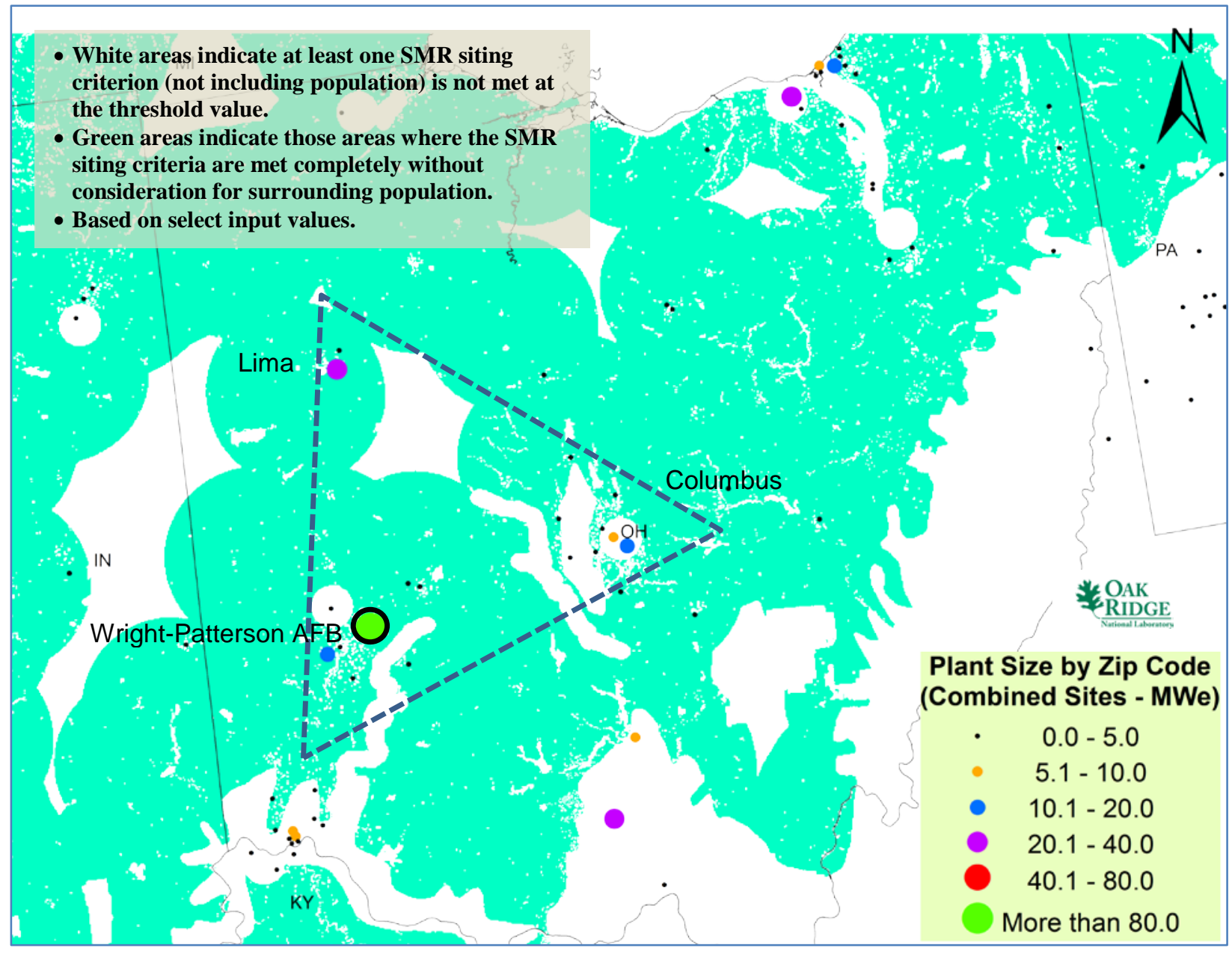

Fig. 16. Western Ohio area relative to SMR siting criteria. 


\subsubsection{Eastern Tennessee Summary}

The eastern Tennessee area is shown in Fig. 17. Federal facilities are identified by a dot relative in size and color to the equivalent plant capacity for the collective federal facilities in a given ZIP code area. ORNL is represented by the large green dot in Fig. 17. Areas in green on the map indicate those areas where SMR siting criteria are met completely without consideration for surrounding population. Areas in white on the map are areas where at least one SMR siting criterion (not including population) is not met at the threshold evaluated in the SMR siting report. For example, the Cumberland Plateau west of ORNL and the Appalachian Mountains east of ORNL are excluded because of landslide hazard issues, slope issues, or inclusion as protected land. The large white circles are commercial airports associated with larger cities. The streak of green area running from the southwest to the northeast is the Tennessee Valley with significant area where SMR siting would be favorable. There are additional federal facilities in the ORNL area with unreported federal energy use data, so the energy demand in this location is higher than what is depicted in Fig. 17. In addition, ORNL includes a HEMSF with forecast energy demand growth.

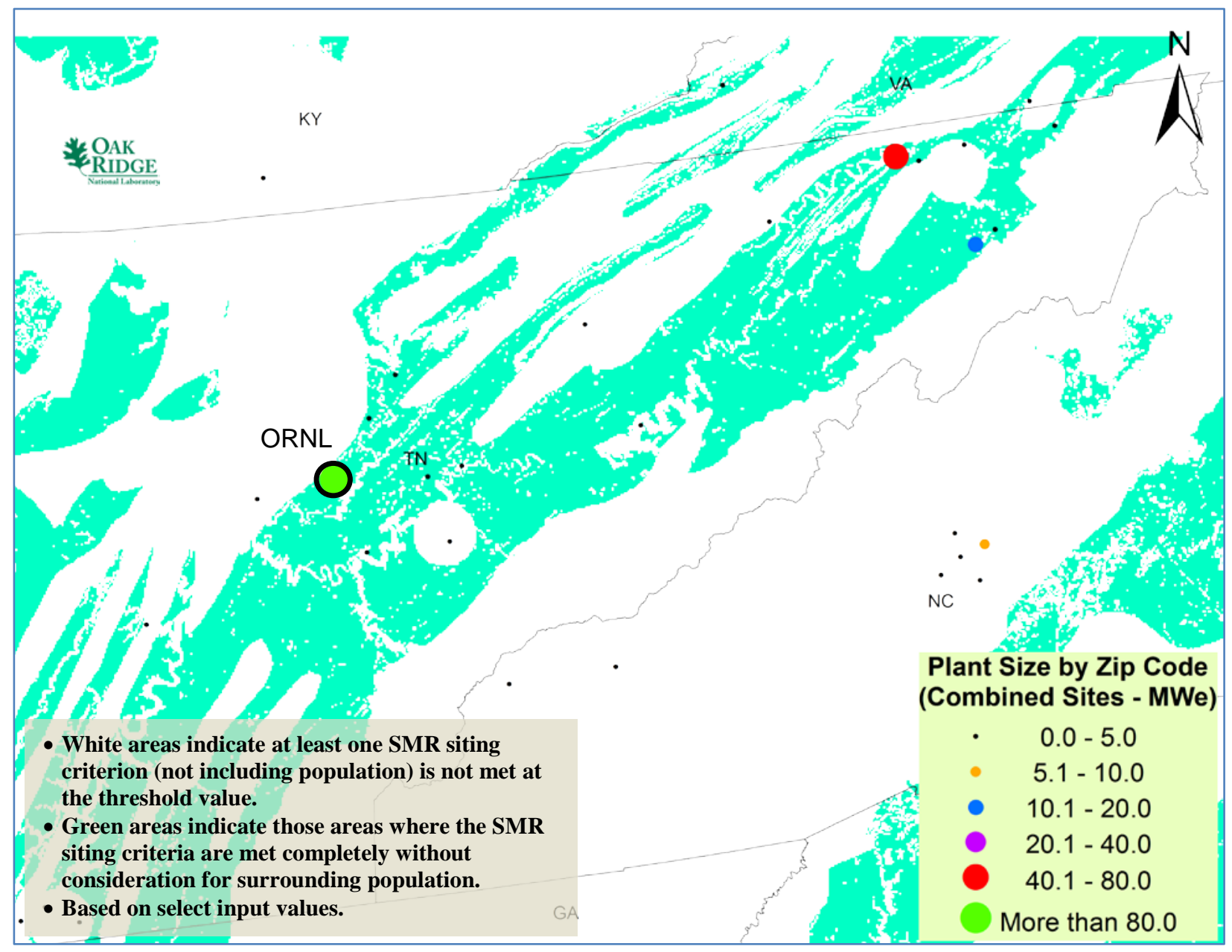

Fig. 17. Eastern Tennessee area relative to SMR siting criteria. 


\subsubsection{Chicago Summary}

The Chicago area is shown in Fig. 18. Federal facilities are identified by a dot relative in size and color to the equivalent plant capacity for the collective federal facilities in a given ZIP code area. The land mass is identified by black shoreline. Areas in green on the map indicate those areas where SMR siting criteria are met completely without consideration for surrounding population. Areas in white on the map are those where at least one SMR siting criterion (not including population) is not met at the threshold evaluated in the SMR siting report. For example, the large white circles are associated with the two Chicago commercial airports. The Great Lakes Naval Training Center is represented by the large red dot to the north in Fig. 18. Fermi National Accelerator Laboratory is approximately 40 miles southwest of the training center, and Argonne National Laboratory is approximately 17 miles southeast of Fermilab. There is significant area around Chicago where SMR siting would be favorable. However, dense population in the area will be a factor in using an SMR to meet federal clean energy goals in this area.

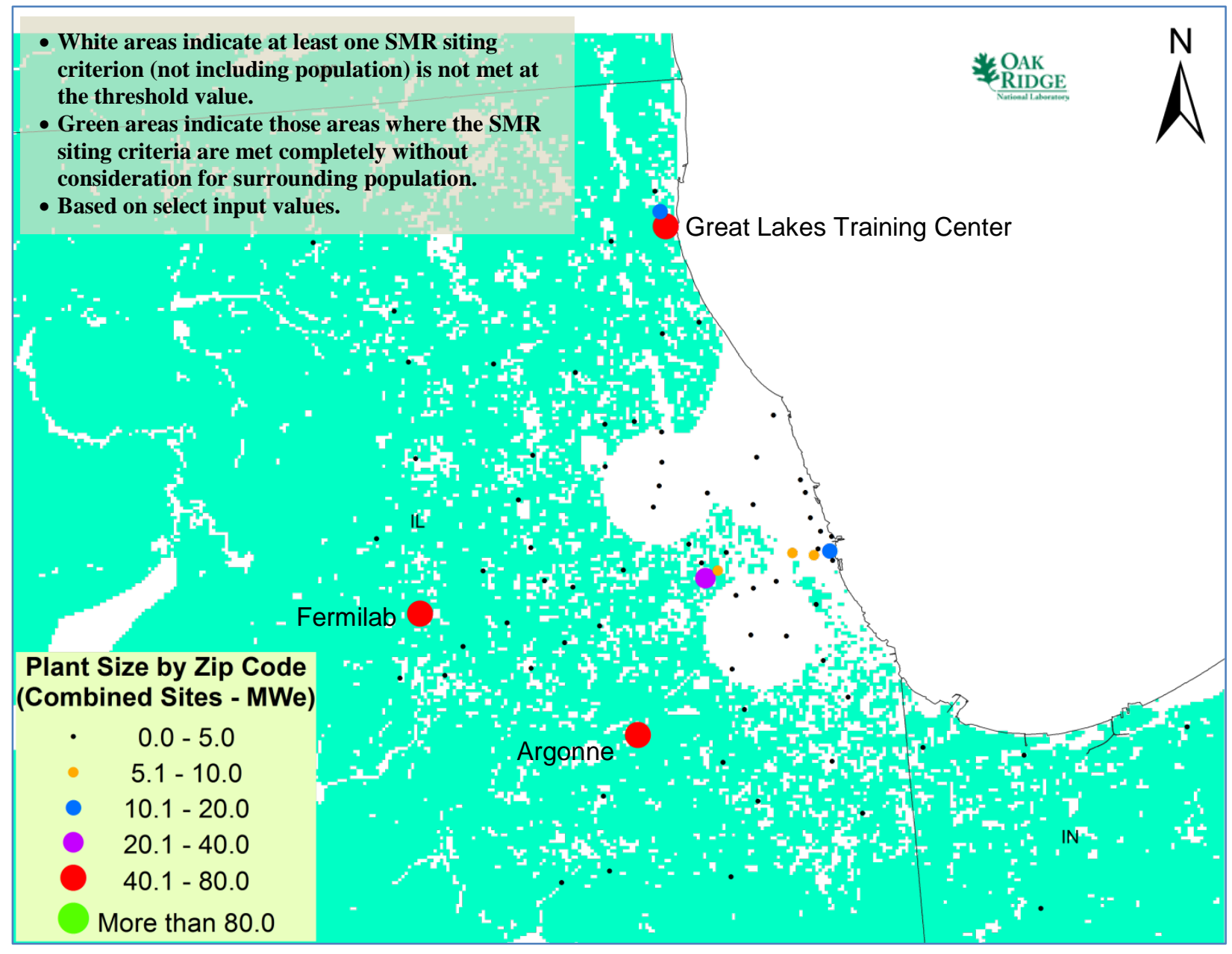

Fig. 18. Chicago area relative to SMR siting criteria. 


\subsubsection{Oklahoma and North Texas Summary}

The Oklahoma and northern Texas area is shown in Fig. 19. Federal facilities are identified by a dot relative in size and color to the equivalent plant capacity for the collective federal facilities in a given ZIP code area. Areas in green on the map indicate those areas where SMR siting criteria are met completely without consideration for surrounding population. Areas in white on the map are those where at least one SMR siting criterion (not including population) is not met at the threshold evaluated in the SMR siting report. For example, significant area in the oval of interest in Fig. 19 is white based on a lack of sufficient makeup cooling water. The large white circles are commercial airports associated with larger cities. Tinker Air Force Base is represented by the large green dot in Fig. 19. The dotted oval is a possible federal energy cluster extending approximately 120 miles from Tinker Air Force Base south to Sheppard Air Force Base in north Texas. Area is available on a limited basis within the oval where SMR siting would be favorable.

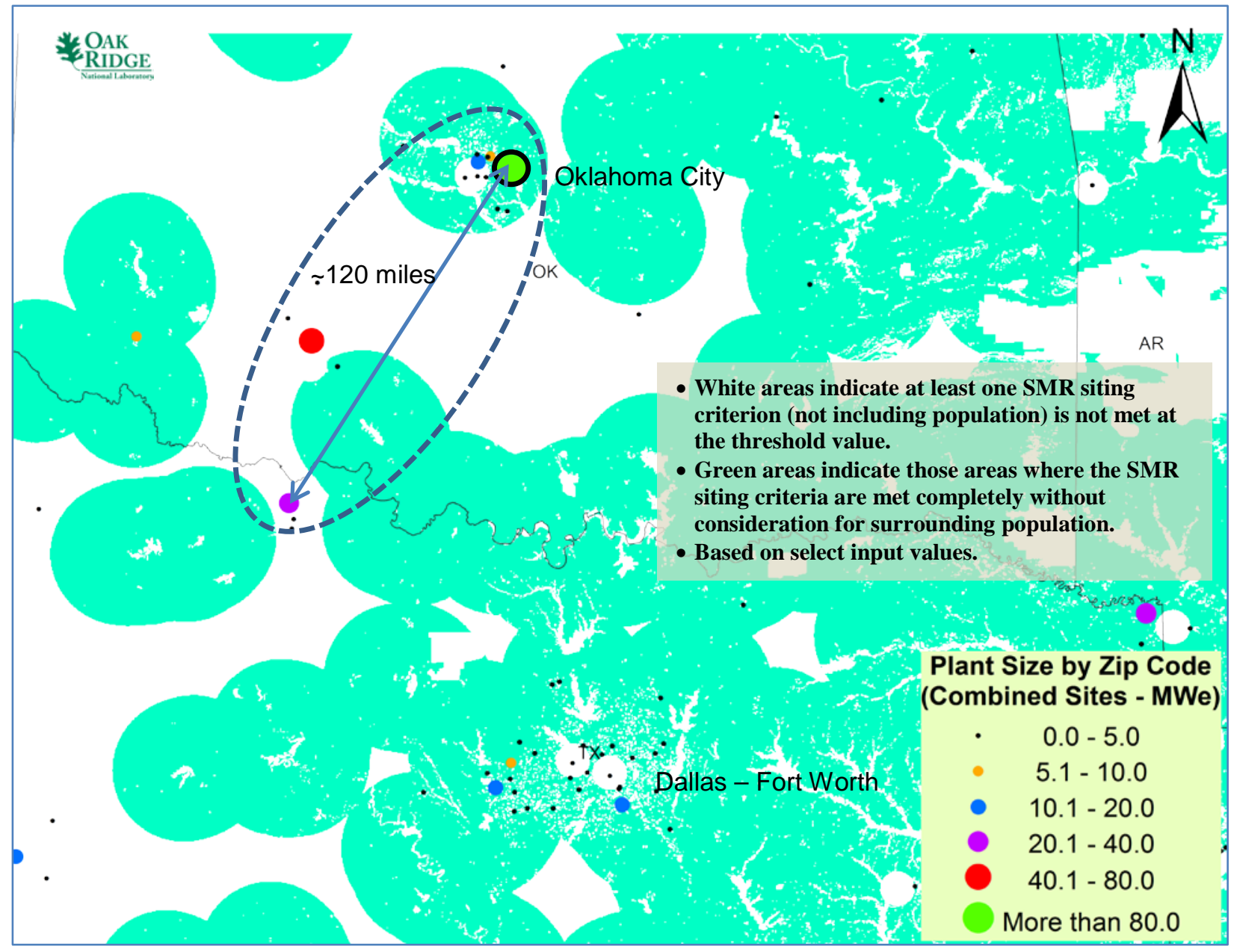

Fig. 19. Oklahoma and North Texas area relative to SMR siting criteria. 


\subsubsection{South Central Texas Summary}

The south central Texas area is shown in Fig. 20. Federal facilities are identified by a dot relative in size and color to the equivalent plant capacity for the collective federal facilities in a given ZIP code area. The land mass is identified by black shoreline. Areas in green on the map indicate those areas where SMR siting criteria are met completely without consideration for surrounding population. Areas in white on the map are those where at least one SMR siting criterion (not including population) is not met at the threshold evaluated in the SMR siting report. For example, significant area west of the oval of interest in Fig. 20 is white based on a lack of sufficient makeup cooling water or because it is protected land. The large white circles are commercial airports associated with larger cities. The dotted oval is a possible federal energy cluster extending approximately 120 miles from Fort Hood south to various facilities in San Antonio. There is significant area within the oval where SMR siting would be favorable. An alternative smaller federal energy cluster can also be proposed around the immediate San Antonio area.

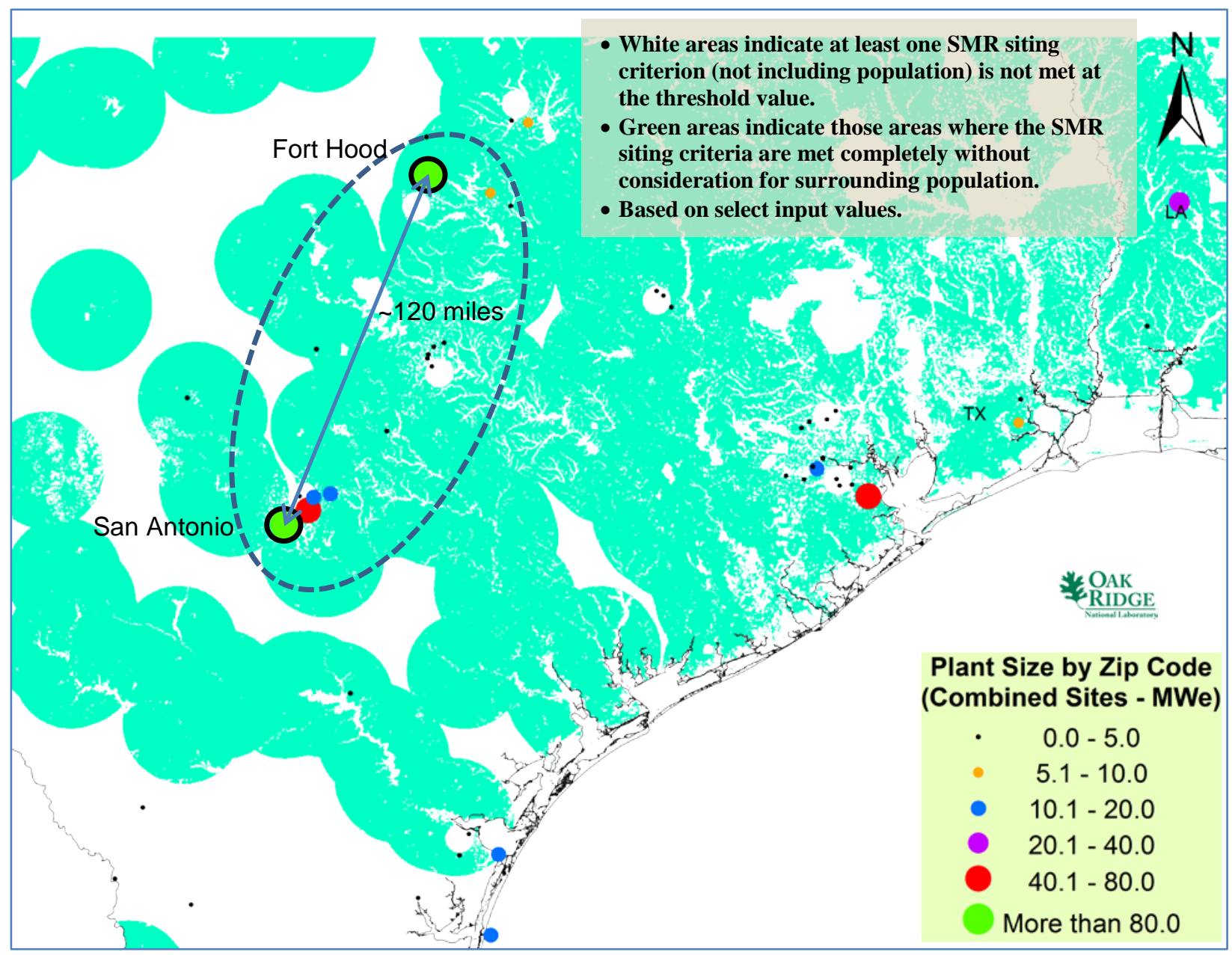

Fig. 20. South central Texas area relative to SMR siting criteria. 


\subsubsection{Central Colorado Summary}

The central Colorado area is shown in Fig. 21. Federal facilities are identified by a dot relative in size and color to the equivalent plant capacity for the collective federal facilities in a given ZIP code area. The land mass is identified by black shoreline. Areas in green on the map indicate those areas where SMR siting criteria are met completely without consideration for surrounding population. Areas in white on the map are those where at least one SMR siting criterion (not including population) is not met at the threshold evaluated in the SMR siting report. For example, significant areas in Fig. 21 are white based on a lack of sufficient makeup cooling water, high slope, or because they are protected land. The dotted oval is a possible federal energy cluster extending approximately 70 miles from Denver south to Fort Carson. There is very limited area within the oval where SMR siting would be favorable.

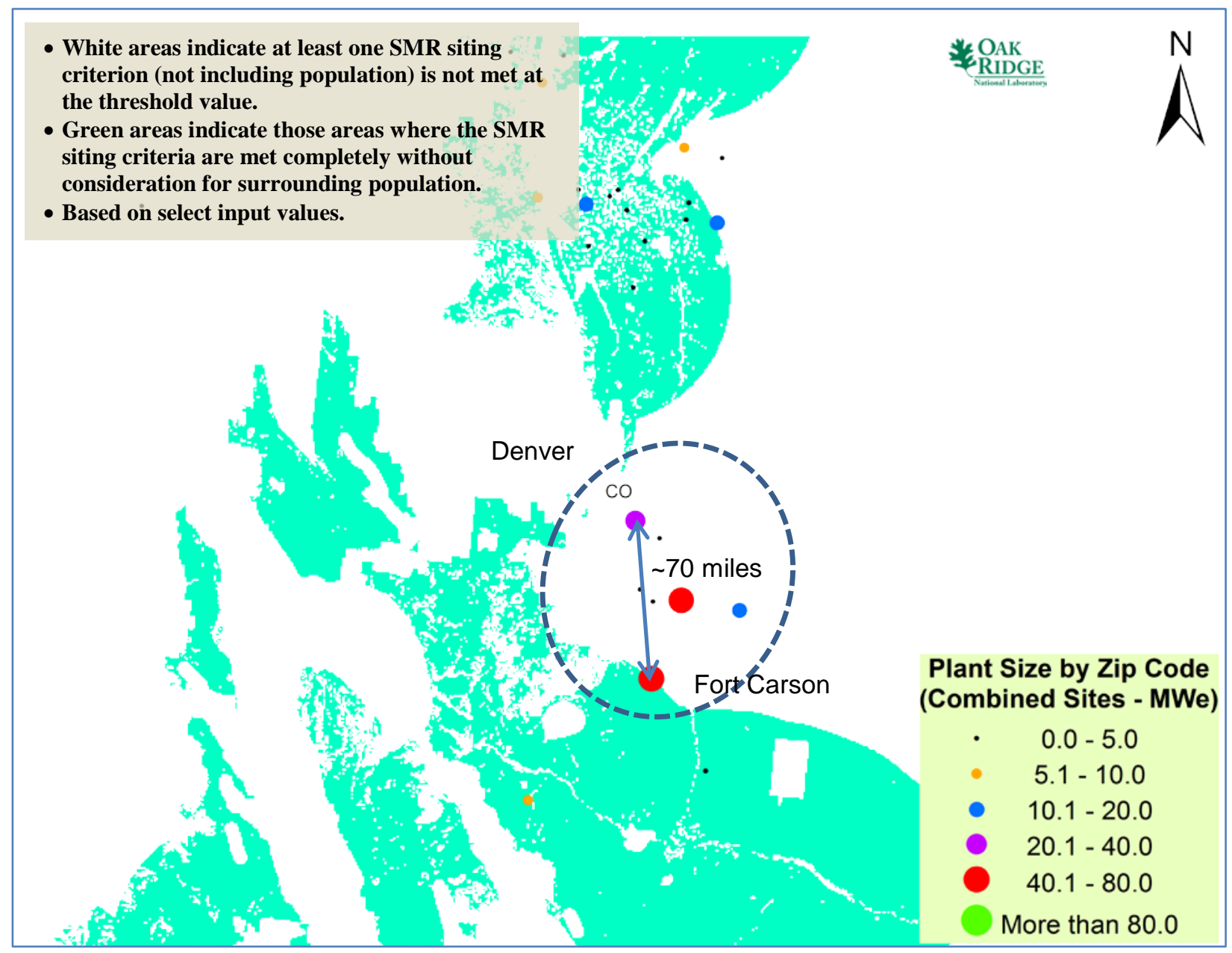

Fig. 21. Central Colorado area relative to SMR siting criteria. 


\subsubsection{Southern California Summary}

Area in southern California is shown in Fig. 22. Federal facilities are identified by a dot relative in size and color to the equivalent plant capacity for the collective federal facilities in a given ZIP code area. The land mass is identified by black shoreline. For reference, San Diego, California, is located in the vicinity of the concentration of blue dots on the southern California coast in Fig. 22. Areas in green on the map indicate those areas where SMR siting criteria are met completely without consideration for surrounding population. Areas in white on the map are those where at least one SMR siting criterion (not including population) is not met at the threshold evaluated in the SMR siting report. Much of southern California is white because it is excluded as a result of exceeding the safe shutdown earthquake threshold, the location of fault lines, inadequate stream flow for cooling water makeup, excessive slope, or protected land. The dotted rectangle is a possible large area federal energy cluster. There is very limited area within the rectangle where SMR siting would be favorable, and long transmission distances would be required. For scale, approximately 220 miles separates San Diego and the point where California, Nevada, and Arizona meet. Smaller clusters are possible around San Diego or Los Angeles; however, there is no favorable SMR siting areas apparent at these locations without consideration of other SMR SSEC threshold values.

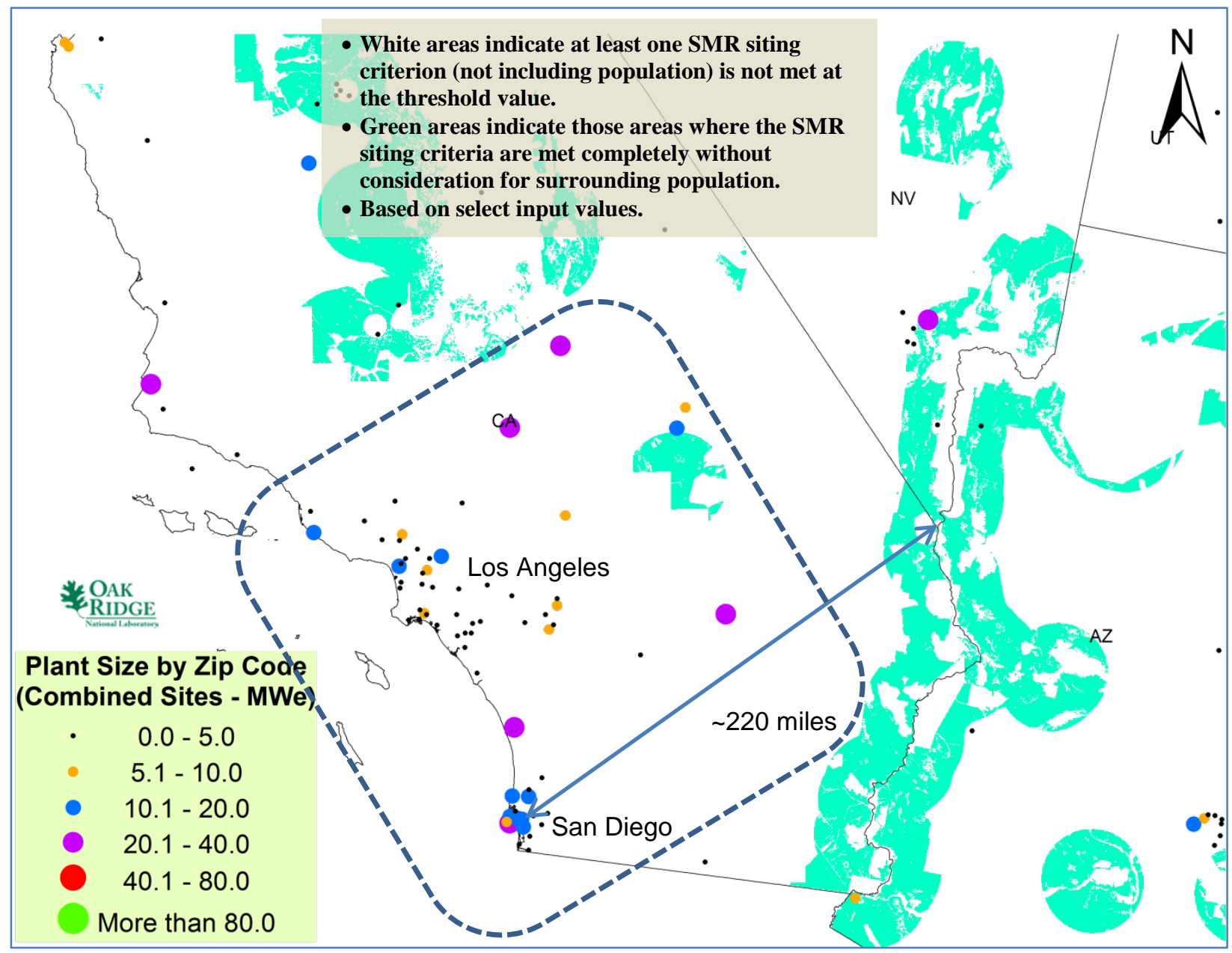

Fig. 22. Southern California area relative to SMR siting criteria. 


\section{SUMMARY}

Energy consumption data for federal facilities over a multi-year period were analyzed mathematically using spreadsheet manipulations of two-digit ZIP code and visually using GIS layers. Energy clusters among these federal facilities were identified using the above methods. Some of the facility clusters are relatively compact, and others require a very broad definition for a facility cluster (i.e., covering a significant distance or range to supply power to all facilities in the cluster). Thirteen clusters identified by one or both methodologies were analyzed against SMR siting criteria, without consideration for surrounding population, based on a previous study on SMR siting. ${ }^{12}$ Eight energy clusters were selected as areas with significant energy consumption based on historical data and providing favorable opportunities for SMR siting to possibly meet federal clean energy goals. The rest of the previously identified clusters were not included in the summary based on a combination of siting criteria deficiencies, lack of a favorable host facility, anticipated extreme population density, or the distance between federal facilities.

The top clusters are identified in Table 5 listing the highest required plant capacity established by mathematical or visual analysis.

Table 5. Summary of Top Federal Energy Clusters

\begin{tabular}{|l|c|c|}
\hline \multicolumn{1}{|c|}{ Location/Facility } & $\begin{array}{c}\text { Plant Capacity to Meet } \\
\text { Energy Demand [MW(e)] }\end{array}$ & $\begin{array}{c}\text { Percentage of Federal } \\
\text { Energy Demand }\end{array}$ \\
\hline Virginia Peninsula/Hampton Roads area & 368.5 & $3.7 \%$ \\
\hline Savannah River Site, South Carolina & 337.1 & $3.4 \%$ \\
\hline Florida Panhandle & 304.9 & $3.1 \%$ \\
\hline South Central Texas & 252.0 & $2.6 \%$ \\
\hline Denver-Colorado Springs, Colorado & 237.8 & $2.4 \%$ \\
\hline East Tennessee/ORNL & 234.3 & $2.4 \%$ \\
\hline Southwest Oklahoma-North Texas & 218.8 & $2.2 \%$ \\
\hline Western Ohio & 206.1 & $2.1 \%$ \\
\hline
\end{tabular}

Federal facilities in the Hampton Roads area are fairly compact relative to one another. SMR siting criteria are not favorable in densely built areas even disregarding any population criteria. However, there appear to be significant SMR siting possibilities all around the fringe of this area, which may also alleviate any population concerns. The number and diversity of federal facilities in this area suggest possibly strong future growth in energy consumption.

Federal facilities in the vicinity of the Savannah River Site in Georgia and South Carolina are also fairly compact relative to one another. SMR siting criteria are favorable throughout this region and could easily be hosted on the Savannah River Site itself. Population is not likely to be a concern in much of this region. If facilities like the MOX fabrication facility are completed, then strong future growth in energy consumption is likely. Otherwise, federal energy demand could be in decline in this area.

Federal facilities within the western portion of the Florida Panhandle are fairly compact relative to one another. A larger cluster can also be envisioned extending into Alabama and Georgia. However, there would be approximately 160 miles between the northernmost and southernmost federal facilities in the 
latter larger federal energy cluster. SMR siting criteria are favorable throughout this region whether the compact federal energy cluster or the larger three-state federal energy cluster is favored. Population is not likely to be a concern in much of this region. Historical energy consumption by federal facilities in this area is predominantly DoD driven.

A larger cluster can also be envisioned in south central Texas extending from San Antonio 120 miles north to Fort Hood. SMR siting criteria are favorable throughout this region though population is a likely factor in the immediate vicinity of San Antonio and Austin. Historical energy consumption by federal facilities in this area is also predominantly DoD driven. Base realignment and closure in the San Antonio vicinity could reduce future energy demand in this region.

Another larger cluster can be envisioned in Colorado extending from Denver 70 miles south to Fort Carson. SMR siting criteria are favorable only in the south in this region. Population will be a factor between Denver and Colorado Springs in the north. Grounds within Fort Carson may provide good SMR siting potential. Historical energy consumption by federal facilities in this area is predominantly DoD driven.

Federal facilities in the Oak Ridge, Tennessee, area are fairly compact relative to one another. SMR siting criteria are favorable throughout the Tennessee Valley, and siting could be hosted on DOE property in this area. Only Oak Ridge National Laboratory reported historical energy consumption data. Other DOE facilities in the area would benefit from an SMR. A larger federal energy cluster could extend 110 miles northeast to Kingsport, Tennessee. The number and diversity of federal facilities in this area suggest possibly strong future growth in energy consumption. Additionally, the Office of Science Composite Sustainability Plan suggests growth in energy consumption at ORNL.

A larger cluster can be envisioned in central Oklahoma extending from Oklahoma City south 120 miles to Sheppard Air Force Base in North Texas. SMR siting criteria are spotty throughout this region, but many favorable sites do exist on the north-south axis of the region. Historical energy consumption by federal facilities in this area is predominantly DoD driven. Base realignment and closure could reduce future energy demand in this region. A smaller cluster surrounding Oklahoma City is also a possibility.

A final federal energy cluster can be envisioned in western Ohio. SMR siting criteria are favorable throughout this region. Historically, Wright-Patterson Air Force Base is the largest federal energy consumer in the region. A triangle with 60 -mile sides between the base and Columbus and Lima, Ohio, comprise this cluster. The number and diversity of federal facilities in this area suggest possibly strong future growth in energy consumption.

The Hampton Roads, Virginia, area will be studied in detail in the follow-on tasks related to this project. However, the remaining selected seven cluster sites, as well as the other five potential federal energy consumption clusters pre-screened out using the OR-SAGE tool, could be studied in more detail as well. Eastern North Carolina has significant federal energy demand and siting that is favorable for SMRs. This area was not included in the final recommended list based only on the spread of the facilities. Likewise, the Chicago area has significant federal energy demand and favorable SMR siting potential without regard for population. This area was not included in the final recommended list based on the spread of the facilities combined with the known dense population in the area of interest. The Seattle, Washington, area fell further down the initial list of possible federal cluster areas; however, this area has reasonable energy demand and is fairly compact. In the ZIP code analysis, Alaska was identified with significant federal energy demand. In particular, the Fairbanks vicinity has reasonable demand. This area was not included in the final recommended list because the OR-SAGE tool is currently limited to analysis of the contiguous United States. In addition, there may be additional unidentified federal energy demand clusters because not all federal facilities reported energy consumption data. Hence, there is significant potential for additional analysis of using SMRs to provide power to clustered federal facilities in order to meet federal clean energy goals. 


\section{REFERENCES}

1. G. T. Mays, T. J. Harrison, and O. A. Omitaomu, Preliminary Report on Siting Evaluation Tool for Commercial Nuclear Power Plants Developed by Oak Ridge National Laboratory, LTR/DOENE/Siting-2010/002, November 2010.

2. R. J. Belles, G. T. Mays, O. A. Omitaomu, and W. P. Poore, Updated Application of Spatial Data Modeling and Geographical Information Systems (GIS) for Identification of Potential Siting Options for Small Modular Reactors, ORNL/TM-2012/403, September 2012.

3. G. T. Mays, R. J. Belles, O. A. Omitaomu et al., Application of Spatial Data Modeling and Geographical Information Systems (GIS) for Identification of Potential Siting Options for Various Electrical Generation Sources, ORNL/TM-2011/157/R1, May 2012.

4. R. J. Belles, G. T. Mays, O. A. Omitaomu, and W. P. Poore, Evaluation of Suitability of Selected Set of Coal Plant Sites for Repowering with Small Modular Reactors, ORNL/TM-2013/109, March 2013.

5. W. P. Poore, R. J. Belles, G. T. Mays, and O. A. Omitaomu, Evaluation of Suitability of Selected Set of Department of Defense Military Bases and Department of Energy Facilities for Siting a Small Modular Reactor, ORNL/TM-2013/118, March 2013.

6. Office of the Deputy Under Secretary of Defense (Installations and Environment), Department of Defense Annual Energy Management Report Fiscal Year 2011, September 2012.

7. DOE Office of Energy Efficiency and Renewable Energy, FEMP EISA 432 Compliance Tracking System, http://ctsedwweb.ee.doe.gov/CTSDataAnalysis/DataAnalysisTool/DataAnalysisTool.aspx, accessed on October 7, 2013.

8. D. T. Ingersoll, “An Overview of the Safety Case for Small Modular Reactors," Proceedings of the ASME 2011 Small Modular Reactors Symposium, Washington, DC, September 28-30, 2011.

9. DOE Office of Energy Efficiency and Renewable Energy, FEMP EISA 432 Compliance Tracking System, http://ctsedwweb.ee.doe.gov/CTSDataAnalysis/DataAnalysisTool/DataAnalysisTool.aspx, accessed on October 7, 2013.

10. DOE Office of Science, Composite Sustainability Plan, April 2013.

11. Office of the Deputy Under Secretary of Defense (Installations and Environment), Department of Defense Annual Energy Management Report Fiscal Year 2011, September 2012.

12. R. J. Belles, G. T. Mays, O. A. Omitaomu, and W. P. Poore, Updated Application of Spatial Data Modeling and Geographical Information Systems (GIS) for Identification of Potential Siting Options for Small Modular Reactors, ORNL/TM-2012/403, September 2012. 